\title{
Sovereign Debtors Before Greece: The Case of Germany
}

\author{
Richard M. Buxbaum*⿻三丨
}

\section{INTRODUCTION}

This article tells a story about the impact of wars and their aftermath on property relations. It uses as a case study the fate of German public-sector and private-sector bonds issued during the Weimar Era and caught up in the turmoil of the $20^{\text {th }}$ Century. It suggests a contestation within the framework of law, politics, and markets that is as relevant today as it was a century ago; it suggests a difference between the life cycles and thus the actionable memories of personal injury and property injury; and it reflects on the institutional architecture within states, societies, economies and cultures that is assigned the mission of bringing the long cycles of debt, default, reengagement, and reargument to some semblance of finality.

More specifically, the account begins where the story that is its subject for now has ended. In 2014 a panel of the Seventh Circuit decided the case of Korber v. Bundesrepublik Deutschland ${ }^{1}$ its facts are so succinctly presented in Judge Easterbrook's opinion that it is the best introduction to the subject matter discussed below:

After Germany surrendered in May 1945, holders of bonds issued by public and private entities in that nation demanded repayment. Germany had suspended payment on many foreign-held bonds during the 1930s, but some prewar bonds were not due until the 1950s or 1960s. A multinational agreement among 21 creditor nations and the

\footnotetext{
* Professor em., Berkeley Law. This is a substantially enlarged version of an earlier paper, Back to the Past: Old German Bonds and New US Litigation, 73 ZAÖRV 1 (2013). In addition to those thanked for help with that paper I add my thanks to Leon Dijkman, LLM 2013 for his substantial help in locating and evaluating Dutch archival materials; to Dr. Martin L. Müller, Director, Historical Division, Deutsche Bank A.G. and to Deputy Director Herbert Karbach, Political Archive of the Foreign Office, Federal Republic of Germany for their friendly and critical support of my inquiries at their respective institutions; and, above all, to Dr. Josef van Elten of the Archive of the Archdiocese of Cologne for his engaged and essential support of my access to German diocesan archives and for his patient explanations of the context within which these materials could be understood.

₹ Personal translations of all German sources are available from the author.

1. 739 F.3d 1009 (7th Cir. 2014).
} 
Federal Republic of Germany ... specified that Germany would pay valid debts outstanding on May 8, 1945. This pact, called the London Debt Agreement, gives priority to creditors who accept diminished payoffs....

Contemporaneously with negotiation of the London Debt Agreement, West Germany enacted a Validation Law requiring holders of foreign debt instruments to submit them to panels that would determine whether the claims were genuine. Some bonds had been bought back in the markets but stolen toward the end of the war; West Germany sought to ensure that these retired debt instruments were not paid a second time and that no counterfeit instruments would be paid. ${ }^{2}$

The conclusion relevant to the following discussion is equally succinct:

Holders could have submitted their bonds for validation decades ago, whether or not they accepted the speed-for-amount tradeoff under the London Debt Agreement; those who delayed have only themselves to blame. ${ }^{3}$

The context, however, needs some elaboration. I begin, therefore, by identifying and briefly describing the debt issues emanating from or incurred by these "public and private entities." 4 All originated during the same era of the 1920s, and all met similar if not identical fates of default, renegotiation, repudiation, and renewed renegotiation between then and the end of the $20^{\text {th }}$ Century. ${ }^{5}$ Their purposes, however, were sufficiently dissimilar to require partially separate discussion.

Four categories of debt instruments are discussed herein. ${ }^{6}$ The first and best-known category consisted of the Reich "reparations bonds," denominated in various foreign currencies and issued by the national government in order to raise the funds needed for satisfaction of the substantial Allied reparation debts to the United Kingdom and France that were imposed in consequence of the Treaty of Versailles - the Dawes and

2. Id. at 1010 .

3. Id. at $1012-13$.

4. Id. at 1010 .

5. This cycle of issuance, default, and (often) renegotiation is hardly a recent phenomenon. For an overview of the more modern epochs during which this course was run, from the beginning of the $19^{\text {th }}$ Century on, see Vinod AgGarwal, DebT Games StRategic InTERACTION IN INTERNATIONAL DEBT RESCHEDULING 15-43 (1996). For an approach by way of structural-cycle theories (e.g., Kondratieff cycles), see also Christian Suter, DebT CyCles IN THE WorldECONOMY 20-24 (1992). And of course one can always begin with Deuteronomy 15:1 (though not for foreign debtors -- 15:3).

6. One important limitation: Debts denominated in German Reichsmark ("RM"), and consequently held mainly though not exclusively by German creditors, are not the subject of this discussion (as will be more particularly qualified below). 
later the Young Bonds. ${ }^{7}$ The second category consists of bonds issued for more traditional purposes by some states of the Reich and many public agencies ranging from specialized development banks to individual municipalities, as well as by a number of private enterprises. ${ }^{8}$ The third category consists of commercial loans granted by foreign financial institutions to private German enterprises. The fourth category is an unusual and little-noted one: German Catholic bodies ranging from major dioceses to obscure abbeys and convents floated approximately 300 separate bond issues during this period. Unlike the first two categories, these typically were bonds of small denominations, of small aggregate amounts, denominated in Dutch gulden, and taken up through the intermediation of a local savingsand-loan institution by Dutch Catholics in the Nijmegen region of the country. ${ }^{9}$

\section{THE ORIGINS}

\section{A. Weimar and the Third Reich: Issuance and Repudiation}

There was a Sorcerer's-Apprentice quality to the original Dawes Plan, in the sense that the success of at least the tranche placed in the United States ${ }^{10}$ "opened the floodgates"

7. To the transformation of this "sovereign debt" to one owed to private claimants and available in secondary capital markets, see JAMES W. ANGELL, THE RECOVERY OF GERMANY 65-76, 333-39 (1929).

8. Within this second category, two sets of bonds need to be separately identified because of their treatment after World War II: bonds issued by the then-State of Prussia and one other set, the so-called Kreuger [Swedish Match Monopoly] Bonds. For a recent overview of the context which led Ivar Kreuger to use a German dollar-denominated bond issue to support his famous monopoly, and the justification for including these instruments in postwar renegotiation efforts, see FRANK PARTNOY, THE MATCH KING 135-55 (2009).

9. See these bonds' listings in Hans-Georg Glasemann, Deutschlands AUSLANDSANLEIHEN 1924-45 (1993). Only three were placed elsewhere; specifically, as goldbacked dollar instruments in the United States. One of these, however, was a pioneer in specifying that the English text would be determinative. See Davidson Sommers, A[aron] Broches, \& Georges R. Delaume, Conflict Avoidance in International Loans and Monetary Agreements, 21 LAW \& CONTEMP. PROBS. 463, 469 n.18 (1956) (treating the seat of the indenture trustee as an indirect choice of New York law).

10. At the starting gun, October 1924 , the US tranche of the Dawes Plan loans, $\$ 110,000,000$ $7 \%$ bonds issued at $92 \%$ of nominal value, swamped the other seven country tranches. Only Great Britain, at $£ 12,000,000$ and Switzerland, at SFr 15,000,000, were even near this range. See ROBERT KUCZYNSKI, AMERICAN LOANS TO GERMANY 43 (1927). The larger context of all foreign borrowings of this era is succinctly provided by J. Reuben Clark Jr., Foreign Bondholdings in the United States, 32 AM. J. INT'L L. 439, 439-46 (1938) (providing the history of the governmentsponsored but privately organized Foreign Bondholders Protective Council, Inc., which played a large role in the postwar renegotiation processes).

11. Frank Costigliola, The United States and the Reconstruction of Germany in the 1920s, 50 Bus. Hist. REV. 477, 494 (1976). 
public-sector and even private-sector entities. ${ }^{12}$ This "torrent" of additional debt issues indirectly defeated the original concept of its author. It changed the basic character of the Dawes Plan, which assumed that the Reparation Bond receipts would stimulate the German economy, as well as provide new tax flows to the point of generating "world economic development."13 Rather, the softening of the world's bond markets, in part due to their flooding with these various new issues, by 1928 demanded higher and higher yields for new issues. This jeopardized the reparations payments and threatened new financial instability. ${ }^{14}$

In 1929 a new arrangement was negotiated that tried to take account of these developments. It reduced the annual reparations transfers to the British and French by one-third, and subordinated these payments to the meeting of interest and amortization payments on private loans. But with the Crash of late 1929 even this was not enough. Economists have long debated the question, whether the shift from the policies underlying the Dawes Plan to those of the Young Plan in fact created unsatisfiable demands that indirectly deepened the looming depression, and more immediately led Germany to impose ever more stringent prohibitions on the use of the state's foreign reserves to meet its trade, private-sector loan, and reparations obligations. $^{15}$

For the purpose of recounting the legal consequences, however, it suffices to document these restrictions. ${ }^{16}$ Beginning in 1932, in the teeth of

12. Whose borrowing totaled almost twice the sum of the Dawes Plan loans; see KUCZYNSKI, supra note 11, at 58. Kuczynski's work is also invaluable on such matters as the factually relaxed nature of the rose-tinted prospectuses, the nature of the indenture covenants, the honoring of amortization schedules, and the oversight (or lack of oversight) of the use of the loan proceeds. According to one source that reviewed all public- and private-sector loans of these three years, "American investors put up 80 percent of the money borrowed by German public credit institutions, 75 percent of that borrowed by local governments, and 56 percent of the loans to large corporations." Costigliola, supra note 12, at 495.

13. Costigliola, supra note 12, at 497. He points out that as a result, the British and French expected cash transfers to meet the reparations claims even though the plan gave repayment of the Dawes loans priority over payment of the reparations they were to fund. Id. For details of the original concept, see HAROLD G. Moulton, THE RePARATION Plan 30-35 (1924). For a later analysis of this expectation (and its eventual disappointment), see WERNER LINK, DIE AMERIKANISCHE STABILISIERUNGSPOLITIK IN DEUTSCHLAND 1921-32 386 (1970).

14. Costigliola, supra note 12, at 499.

15. For a critical overview of this literature, and for the thesis that this shift dramatically and negatively affected the flow of foreign investment to German enterprises to the point of deepening the Depression, see Albrecht Ritschl, Reparation Transfers, the Borchardt Hypothesis and the Great Depression in Germany, 1929-32: A Guided Tour for Hard-Headed Keynesians, 2 EUR. REV. ECON. HIST. 49 (1998).

16. For a detailed account of the various unsuccessful international efforts to come to more satisfactory outcomes that the Weimar government and the markets might accept, including President Hoover's later proposed moratorium on debt repayments, see EDWARD BENNETT, GeRmany AND the Diplomacy OF the FinANCIAL CRISIS, 1931 153-203 (1962). The larger 
the Great Depression, the Weimar Republic in its last stages ${ }^{17}$ and the Third Reich in its early stages ${ }^{18}$ first struggled to avoid or manage the consequences of defaults in all four categories, in particular by declaring and strictly enforcing a moratorium on the servicing of these bond issues with increasingly scarce foreign reserves. In the case of the first two categories of instruments, the government, after 1933, also engaged in partly concealed efforts to lower its servicing and repayment obligations, in particular by using strawmen to buy up deeply discounted bonds in New York and other secondary markets. ${ }^{19}$ A few shorter-term bonds were paid at their maturity upon surrender; others, especially those repurchased by their particular issuers and converted into Reichsmark denominations, then were placed in German secondary markets; yet others were returned by their holders to the issuers in exchange for foreign-denominated or RM-denominated debt instruments issued after 1933 in substitution for Weimar-Era issues. ${ }^{20}$ This

context of efforts to deal with the problems of debt-service defaults by many sovereign debtors during the 1930s is succinctly reviewed and its lessons for the defaults of the 1980 s evaluated in Barry Eichengreen \& Richard Portes, After the Deluge: Default, Negotiation, and Readjustment during the Interwar Years, in The InTERnational DeBt CRISIS IN Historical PerspeCtive 12-47 (Barry Eichengreen \& Peter Lindert eds., 1989).

17. The first major control on foreign-exchange outflows, the VERORDNUNG ÜBER DIE DEVISENBEWIRTSCHAFTUNG, May 23, 1932, RGBL. I at 231 was adopted in the last year of the Brüning (Weimar) era. While it focused on requiring a domestic creditor receiving foreign exchange to transfer it to the Reichsbank, its principal focus already at this time (and even more during the first years of the Third Reich) was on trade imbalances and clearing methods that avoided use of scarce foreign exchange. These are not discussed in this presentation. For a comprehensive review of these mechanisms, see FrANK CHILD, THE THEORY AND PRACTICE OF EXCHANGE CONTROL IN GERMANY 101-32 (1958). For a succinct and sophisticated explanation of the combination of foreign-exchange controls and balancing of trade flows in most countries during the 1930s, see Ulrich Uchtenhagen, Die rechtliche Organisation und die verwaltungsrechtliche Struktur des gebundened Zahlungsverkehrs mit dem Ausland (n.d. [1957]).

18. The most important Third Reich action was the imposition of a moratorium on foreignexchange transfers enacted in 1933, which applied to all four categories. See the GESETZ ÜBER ZAHLUNGSVERBINDLICHKEITEN GEGENÜBER DEM AUSLAND, June 9, 1933, RGBL. I at 349. This and subsequent actions are briefly but adequately described in ANDRE SAYATZ, DAS SCHICKSAL DER REICHSMARK-WERTPAPIERE UND AUF AUSLÄNDISCHE WÄHRUNGEN LAUTENDEN DEUTSCHEN SCHULDVERSCHREIBUNGEN NACH 194550 (1998).

19. An excellent overview of these and the later-referenced practices is provided in Adam Klug, The Economics of Buying Back German Debt in the 1930s, in SELECTED CLIOMETRIC STUdieS On GERMAN ECONOMIC History 296-312 (Scott Eddie \& John Komlos eds., 1997). Klug provides evidence that $35 \%$ of all dollar-denominated Reich- and state-issued bonds had been reacquired by late 1936 through these various transactions. Id. at 299.

20. The two principal prewar debt instruments issued after 1933 by the Third Reich - in partial and eventually repudiated settlement of earlier obligations-were those related to the Konversionskasse and those related to the so-called Standstill Agreements. The former scheme dealt, inter alia, with German private sector debt issues denominated in foreign currency. Debtors serviced these by paying Reichsmark to the Central Bank, which then issued RM-conversion instruments to the foreign creditors in purported payment. They could refuse it, in which case the interest rate was lowered by fiat and the servicing of the principal debt deferred. See supra note 19.

The Standstill Agreements were more or less-and over time less and less-voluntary 
interwar financial history was the subject of substantial public and academic literature at the time, which is not revisited here. ${ }^{21}$ The postwar efforts at resolution of this situation, however, have not been explored as deeply. ${ }^{22}$ Parts $\mathrm{B}$ and $\mathrm{C}$ below take up that subject, examining first the initial period following the end of World War II and then the new disputes that arose following German reunification.

\section{B. The First Postwar Period}

For reasons having to do with the chaos accompanying the ending phase of World War II and the immediate postwar years, the appearance of many of the first two categories of bonds in the hands of thieves and fences was a matter of much concern to the Western Allies and the West German public authorities of that time. The origins of dubious secondary transactions are varied. ${ }^{23}$ Some of the Reich and state bonds that had been surrendered after

arrangements with foreign banks, in essence rolling their short-term claims over, even as more debt of the same type was incurred and added to the total. See Neil Forbes, London Banks, the German Standstill Agreements, and 'Economic Appeasement' in the 1930s, 40 ECON. HIST. REV. 571 (1987); URSUlA ROMBECK-JASCHINSKI, DAS LONDONER SCHULDENABKOMMEN 34 (2005). A useful more general overview is that of HAROLD JAMES, THE REICHSBANK AND PUBLIC FINANCE IN GERMANY: 1924-1933 218-55 (1985).

21. Two early postwar publications written before the London Debt Agreement (fort text see infra note 28) resolved the prewar defaults. For discussion of these problems from a nearcontemporaneous perspective see Edwin Borchard, STATE INSOLVENCY AND FOREIGN Bondholders Volume I General Principles 213 (1951) and William Wynne, State INSOLVENCY AND FOREIGN BONDHOLdERS VOLUME II SELECTED CASE Histories OF Governmental Foreign Bond Defaults And DeBt Readjustments 281 (1951). Some references to prewar literature on these practices also are provided in JASCHINSKI, supra note 21, and ULF SIEBEL, RECHTSFRAGEN INTERNATIONALER ANLEIHEN 110 (1997).

22. Some academic and professional commentary, usually specific to a regulatory or case development, did appear in the journal WERTPAPIER MITTEILUNGEN [hereinafter WM], which as its name suggests was founded (in 1949) originally for the specific purpose of reporting on the postwar developments concerning these prewar debt issues.

23. Some litigants have attempted to cast doubt on the entire factual basis underlying the more or less official narrative. See Bleier v. Bundesrepublik Deutschland, No. 08 C 06254, 2011 WL 4626164 (N.D. Ill. 2011), aff'd (in Korber), 739 F.3d 1009, 1009-13 (7th Cir. 2014), cert. denied, 134 S. Ct. 2729 (2014) (providing a strident pleading on this point). A claim that the U.S. action constituted a taking was launched by Bleier's attorney on his own behalf, using a similar argument; see Abbas v. United States, 124 Fed. Cl. 46 (2015). However, that narrative became and remains the legal framework for postwar consideration of these debt claims.

The basis for this standard approach of judicial deference to legislative (or treaty) fact-finding is well explained in World Holdings, LLC v. Fed. Republic of Germany, 794 F. Supp. 2d 1305, 1330-36 (S.D. Fla. 2011), aff'd, 701 F.3d 641 (11th Cir. 2012), cert. denied, 134 S. Ct. 203 (2013). Yet a third effort was rejected by the First Circuit on "non-validation" grounds like those determinative of Korber, supra note 23, at 1012-13. See Fulwood v. Fed. Republic of Germany, 734 F.3d 72, 81 (1st Cir. 2013).

For an important analogous German rejection of factual challenges to treaty and legislative findings that underpinned the relevant legislation of the post-unification period, see Bundesverfassungsgericht [BverfG] [Federal Constitutional Court], Apr. 18, 1996, 94 BVERFGE 12. 
their payment upon maturity, or that had been exchanged for post-1933 debt instruments, were not returned for cancellation after the beginning of World War II. Others had been purchased by the German government after 1933, but could not be physically cancelled without the cooperation of the foreign trustees and thus rested uncancelled in the depositary's vaults. ${ }^{24}$ After 1945 many of these were seized or plundered from the Reichsbank vaults by Soviet military units and over time turned up in a variety of West German, Allied, and Neutrals' secondary markets - markets ranging from stock exchanges to taverns. ${ }^{25}$

The consequence of this turbulent situation was the enactment, first by the Western Allies' Occupation Authorities ${ }^{26}$ and after 1949 by the Federal Republic, of legislation designed to separate the wheat from the chafflegislation culminating in the Law for the Validation of German Foreign Currency Bonds. ${ }^{27}$ This legislative framework, adopted to establish a

24. See the discussion of these circumstances in Joachim Heintze, Die Bereinigung der deutschen Auslandsbonds, 4 WM 367 (1952).

25. A German decision resolving a dispute between a buyer and seller of these instruments vividly describes this scenario:

The defendant owned an inn in West Berlin. During 1946-47 many former bank and stock-exchange employees frequented it; there they also dealt in financial papers, since at the time there was no official exchange in Berlin. The defendant agreed to attempt to sell such securities in the Western Zones [of Occupation], and to this end made contact with " $Z$ ", to whom an intermediary had referred him.

$\mathrm{Z}$ did not ask the defendant about the provenance of the instruments, and neither asked for his ID nor for any official proof concerning his acquisition of these instruments. He also did not demand the "Western Zone" certification, required at that time, to the effect that the documents had been located in one of the three Western Zones since before January 1, 1945.

Bundesgerichtshof [BGH] [Federal Court of Justice], Dec. 16, 1952, 15 BGHZ 223.

For a US version of this context, see Abrey v. Reusch, 153 F. Supp. 337, 343 (S.D.N.Y. 1957). A subcommittee of the Senate Committee on the Judiciary became involved in this matter on the suspicion that a similar situation was presented by Abrey's claim. See Scope of Soviet Activity in the U.S.: Hearing of the Subcomm. to Investigate the Admin. of the Internal Sec. Act and Other Internal Sec. Laws, 85th Cong. 1st Sess. (1957). A newspaper report on the hearing led to an unsuccessful libel suit. See Abrey v. New York World-Telegram Corp., 164 N.Y.S.2d 632, 635 (N.Y. Sup. Ct. 1957).

26. In lieu of primary citations to these several promulgations, see their listing in Schoele, Die Wertpapierbereinigung, 4 JR 300 (1950). The principal statute, Law No. 155 of 19 August 1949, was published in the somewhat obscure GeSETZBLATT DER VERWALTUNG DES VEREINIGTEN WIRTSCHAFTSGEBIETES I at 295 [Official Journal of the Administration of the France/UK/US "Trizone"].

27. BereinigungsGesetZ FÜR DEUTSChe Auslandsbonds, 1952, BGBL. I at 553. A similar law focused on Reichsmark-denominated obligations; see its most important pre-unification formulation: WERTPAPIERBEREINIGUNGSSCHLUSS GESETZ, Jan. 28, 1964, BGBL. I at 45. The many 
validation process for holders seeking to establish legitimate title to their securities, rested on two critical distinctions: (1) that between pre-WW II bonds held by claimants residing abroad and those held by claimants residing in Germany; and (2) that between securities whose issuers were located in territories that after WW II became part of the Federal Republic ${ }^{28}$ and those whose issuers were located in those that became part of the German Democratic Republic.

This legislation did not purport to change the substantive law applicable to the debt claims, with one exception noted below. Rather, it and its implementing regulations set forth the procedures pursuant to which the holders of these bearer instruments could obtain the validation of their title. That in turn rendered them eligible for current or future payment to the extent provided by other norms, in particular by the settlement and exchange processes undertaken pursuant to the multinational London Debt Agreement of $1953 .{ }^{29}$ Concerning the first distinction referenced above, the law and regulations distinguished among three types of holders: foreign holders, domestic (German) holders, and persons who had regained possession of earlier-expropriated securities (usually expropriated or sold under duress in the course of Third-Reich measures directed principally against Jewish property owners).

Foreign (non-German) holders of debt instruments - of both types of denominations - that on January 1, 1945 were located outside the German borders of December 1, 1937 generally obtained a validation certificate simply upon presentation of the bonds to the validation agencies. In the case of instruments that after 1945 had been restored to foreign residents in Allied countries (principally in the UK and US), from whom Allied authorities had temporarily confiscated them under wartime Alien Property regulations, an unimpeachable certificate of legitimate ownership also was issued simply upon proof of those instruments' return. In other words, the nature and legitimacy of their holders' prewar claim to title were not subject to challenge.

Reich and "West German" bond and note issues that on January 1, 1945 were held in the territory of what later became the Federal Republic of

statutory revisions and extensions up to the date of reunification are listed in the Unification Treaty's Annex, Annex I, Chapter IV [legislation under the administrative implementation of the Federal Ministry of Finance], Subject-Matter A: Regulation of the Consequences of War, Part I, items 1-10; most conveniently gathered in KLAUS STERN \& BRUNO SCHMIDT-BleibTREU, VOL. 2 EINIGUNGSVERTRAG 374 (1990).

28. There were some exceptions, as discussed further below.

29. Agreement on German External Debts, Feb. 27, 1953, 333 U.N.T.S. 3. The German statute incorporating the LDA into its domestic legislation may be found at 1953, BGBL. II at 1200 . 
Germany, ${ }^{30}$ however, could be validated only if their holders could meet a heightened version of the generally applicable Civil Code requirements of legitimate ownership. The Soviet plunder issue was probably the principal basis for this additional screening process. But there was another reason. In an unknown number of cases, the predecessors in the chain of title of bonds now held and presented by German postwar holders might have been Jewish or other victims of Third-Reich persecution (or, as in the case of the occupied Netherlands, forced to accept repayment in Reichsmark at a questionable exchange rate). This created an additional evidentiary issue that had to be faced. These instruments typically were bearer instruments. Ordinarily, claims based on good-faith acquisition of bearer instruments enjoy a German-indeed general Civilian-presumption of legitimate ownership. This presumption, however, was expressly rendered inapplicable by the statutory validation regime, given the typically involuntary circumstances under which these instruments had been originally transferred.

The third type of claim represented the other side of this coin and involved those victims. Debt instruments that under postwar restitution measures had been returned to claimants from whom they had been confiscated were granted validation certificates without further proof. This was no more than the understandable consequence of the fact that these claimants had provided sufficient proof of their original ownership and confiscation to regain possession of these instruments after January 1, 1945 under the general postwar restitution ordinances and statutes in the first place.

Holders of debt instruments issued early after World War II by the Federal Republic, and thus not tainted by the mentioned problems of illegitimate acquisition, by definition had legitimate title. This particular category of bonds, however, represented instruments substituted for prewar bonds; indirectly, therefore, they too had been subject to the filtering process in the sense that the original instruments were required to pass through the described alternative validation procedures before these later instruments could be issued to their holders. It also will be relevant to the later discussion of the current litigation that the holders had accepted these postwar successor instruments through a compromise settlement

30. Note that this foreshadows an East-West classification. Debt instruments of lower-level authorities located in what became the GDR were not eligible for validation let alone for the LDA settlement schemes. And while GDR subjects attempting to validate their ownership of Reich and lower-level "West German" issuers' instruments were eligible to present them for validation, practical difficulties in obtaining GDR approval of their efforts in essence prevented these applications, as discussed further below. 
arrangement that included a reduction of the amount due on their original claims. ${ }^{31}$ Specifically, under the terms of the London Debt Agreement of $1953,{ }^{32}$ the Federal Republic made settlement offers to the holders of these validated prewar instruments (principally the Dawes and Young Bonds and the mentioned Prussian and Kreuger bonds), offers that basically extended their dates of maturity and lowered the original rates of interest. By 1960, at which time the previously described validation processes essentially had been completed, the large majority of holders of these validated bonds had accepted these offers and been issued these new instruments, so-called conversion bonds. ${ }^{33}$ These traded in secondary markets until the last of them was redeemed in the mid-1980s.

Two other postwar instruments, representing interest arrearages for two specific time periods, also are part of the picture. One type, the so-called "shadow quota" certificates, represented the unpaid interest arrearage claims accrued between the time of original issue and the end of World War II. These were claims the LDA settlement offer had not addressed and that thus had been left unsatisfied. Some of these certificates were issued as coupons alongside the first-described conversion bonds, others of later vintage were issued as separate talons or as warrants exchangeable for the first two forms.

The second type of postwar debt issue represented a different interest arrearage. The LDA had deferred any consideration of one particular set of unpaid interest claims until the uncertain date of a later comprehensive reparations settlement; in essence, until eventual reunification. That set represented the interest that had accrued between the end of the war in 1945 and the effective date of the arrangements contemplated by the LDA itself, specifically 1952. This basket of interest accruals was reified in a new set of debt instruments issued much later, with an effective date of October 3, 1990 (the day of formal reunification).

In summary, the postwar story so far concerns the various substitute (conversion) instruments, the notes representing pre-1945 unpaid interest, and the notes representing 1945-1952 unpaid interest. All three types of

31. The plaintiff in Mortimer Offshore Servs., Ltd. v. Fed. Republic of Germany alleged that its Weimar-era bonds had not needed to pass through the validation process and thus by definition had not been submitted in response or subject to the LDA settlement offers. 615 F.3d 97, 104 (2d Cir. 2010), cert. denied, 562 U.S. 1249 (2011). That issue will be discussed below.

32. See Agreement on German Debts, supra note 30.

33. So characterized because in essence they were the postwar substitutes for the instruments issued by the Konversionskasse during the Third Reich, which themselves substituted Reichsmarkdenominated instruments for the deferred servicing of the various foreign-currency instruments issued during the Weimar period. See supra note 19. For the details of this set of prewar and postwar instruments, see in particular HANS-GEORG GLASEMANN, DiE SCHULDTITEL DER KONVERSIONSKASSE FÜR DEUTSCHE AUSLANDSSCHULDEN 1933-1945 (2009). 
debt instruments were paid at various maturity dates; the last of them (representing the 1945-1952 arrearages) on October 1, 2010, almost twenty years to the day after reunification. ${ }^{34}$

Finally, it is worth recalling that US agencies and courts also had been involved in the handling of claims that had to be validated if their holders wished to accept the LDA settlement offers. The LDA provided a simplified validation procedure for dollar-denominated bonds originally placed in the United States. ${ }^{35}$ Under the terms of a bilateral agreement that supplemented the general validation procedures the LDA provided for settling a variety of prewar and postwar claims against the Federal Republic, a US Board for the Validation of German Bonds was established to which US-based holders could present their claims and evidence without having to resort to these processes in Germany. ${ }^{36}$ The Board's findings were subject to review by a federal court and substituted for the processes and decisions of the German authority in charge of these validation procedures. ${ }^{37}$ Its positive decisions were entitled to automatic recognition by the German office responsible for

34. Edith Palmer, Germany: Dawes and Young Plan Bonds Paid Off, The LaW LiBrary OF CONGRESS (Oct. 28, 2010), http://www.loc.gov/lawweb/servlet/lloc_news?disp3_205402337_text.

35. The LDA also made similar arrangements for bonds placed elsewhere, but I do not discuss those analogous procedures here.

36. As earlier mentioned, holders of these instruments who before January 1, 1945 had resided in the US received a validation certificate more or less automatically. It was persons now in the US who could not meet that earlier-residence standard and who had to present the full chain of title which the basic German legislation required who benefited from this US-venue alternative. See Abrey v. Reusch, 153 F. Supp. 337, 342-43 (S.D.N.Y. 1957). That was something of a political cause celèbre at the time. On the availability of arbitration as a remedy against a negative decision of the US Board, see Cavac Compania Anonima Venezolana de Administracion y Comercio v. Bd. For Validation of German Bonds in the U.S., 189 F. Supp. 205, 207-08 (S.D.N.Y. Oct. 27, 1960).

37. For an exhaustive recounting of the variety of claims, and especially of the variety of unsuccessful efforts to obtain validation of dubious holdings, see Third Annual Report of the Validation Board for German Dollar Bonds (1956), in U.S. DeP'T of STATE Bulletin, Vol. XXXVI, No. 924, Mar. 18, 1957, 443. It provides vivid chapter and verse of these attempts.

If only to avoid a misunderstanding (and to mark a centennial anniversary), this is the place at which to point out that art. 5(1) of the LDA apparently deferred all payments based on post-World War I claims of both private and state parties recognized during the interwar period by various bodies - in the US case, the "Mixed Commission" awards based on a special 1922 bilateral agreement rather than on the multilateral arrangements provided by the Versailles Treaty (since the US had not joined the League of Nations that administered these arrangements). As a result, the US successfully argued that art. 5(1) did not apply; this in turn led to a separate post-1953 bilateral agreement that negotiated an installment-payment plan for its awards. The "centennial anniversary" concerns the so-called "Sabotage Claims," most prominently the Black Tom Explosion of 1916. The full story is well-told in BURKHARD JÄHNICKE, WASHINGTON UND BERLIN ZWISCHEN DEN KRIEGEN (2003). For more or less contemporaneous explanations of the work of the Commission, the source of funds already paid on private claims before World War II, and the competition among claimants, see Z. \& F. Assets Realization Corp. v. Hull, 311 U.S. 470, 480-86 (1941) and Edwin Borchard, The Settlement of War Claims Act of 1928, 22 AM. J. INT’L L. 373, 374 (1928). 
payment of the settled claims. ${ }^{38}$

One critical limitation, however, applied to all of these instruments. The postwar division of the German Reich, and the creation in 1949 of two Germanys - the Federal Republic and the German Democratic Republicbrought with it an anachronistic distinction. While Reich bonds, state (principally Prussian) bonds and Kreuger bonds (Prussian by ascription) were eligible to be presented, ${ }^{39}$ bonds issued by those lower-level public and by private issuers which after the war were located in the GDR were not.

\section{The Disputes Following German Reunification ${ }^{40}$}

These prewar "East German" instruments and the difficult situation of East German holders of even Reich, Prussian/Kreuger, and "West German" prewar instruments presented a yet different problem, one related to the Cold War and the division of Germany. As described above, holders of prewar national or "West German" foreign currency-denominated bonds who could not meet these various requirements of legitimate ownership suffered their cancellation. That consequence, however, assumed an application for validation of instruments eligible for presentation had been made and rejected, or had not been made in a timely manner (though the prescription period was extended more than once). With the reunification of Germany and the reappearance of debt instruments that had not been eligible for the LDA settlement arrangements, however, new ownership claims were inevitable. And because the same problems of looted and voided but uncancelled instruments that led to the original legislation remained a concern after unification — indeed, were more of a concern ${ }^{41}$ - the validation

38. I leave aside one significant complication. While validation proceedings in other countries were efficiently completed on a collective basis because the affected bonds were held by a central registration agency, the number of US intermediary institutions involved led to a more cumbersome and individualized screening procedure. The delay this occasioned led to some friction between the US and German validation bodies.

39. Prussian bonds were eligible because after the war a considerable part of what had been Prussian territory was located in the Federal Republic; Kreuger bonds because of their Prussian location of issuance. See PARTNOY, supra note 9.

40. An excellent presentation and analysis of these matters, fully and clearly detailed, is provided in SAYATZ, supra note 19. As the title suggests, his treatment covers the entire postwar historical period.

41. The reasons why this was an increased concern are vividly described in Tilman Bezzenberger, Die vagabundierenden Reichsmark-Effekten aus der ehemaligen DDR und die Grenzen des Wertpapierrechts, 46 WM 2081, 2082 (1992). While, as the title indicates, he addresses those bonds not denominated in foreign currencies, the story here paraphrased applies to both types: From the 1950s on, large numbers of financial instruments of dissolved public and private issuers landed in the GDR state archives. In the 1980s, to procure foreign currency, these large collections were sold - not in secondary exchange-like markets but to antique dealers specializing in historical financial papers. 
procedures long dormant and long barred through prescription by 1990 indirectly became problematic. ${ }^{42}$

The Unification Treaty provided that both the domestic-currency and the foreign-currency validation statutes did not apply in the new states (Länder) of the former GDR. ${ }^{43}$ The brief legislative comment to this abrogation states only that by now these laws had achieved their purpose. ${ }^{44}$ So far as foreign and West German bondholders (of Reich, Prussian, Kreuger and "West German" issues) were concerned, that was in part correct in the sense that the applicable prescriptive periods had run by 1990, but with two exceptions. One recurring issue concerns bondholders who had rejected the LDA compromise and, by the terms of that treaty, had their claims deferred until all acquiescing bondholders had been satisfied upon maturity and payment of the mentioned substitute instruments. The other exception concerns prewar debt instruments issued by "East German" entities and East German holders of both these and RM- and foreign-currency instruments falling under the LDA; that is, the Reich, Prussian and Kreuger bonds as well as bonds issued by sub-state entities located in postwar West German territory. These bondholders had been eligible to participate in the validation and LDA processes but by and large had been prevented from doing so by the GDR.

The larger problem lurking behind these problems, however, was not the rights of these holders but the revival of claims on "East German" bonds, ranging from Weimar-era issuances of the states of Saxony and Anhalt down to single-municipality instruments (such as those of the City of Dresden, of which more below).

Before delving into these complexities one separate approach to this

The German Democratic Republic also tried tapping into savings across the German divide, by means of the issuance of DM-denominated floating-rate notes. See Richard Benzie, The Development of the International Bond Market, 32 BIS ECON. PAPERS, Jan. 1992, at 12-18. According to Benzie, the Federal Republic even at that time-prior to unification but after its recognition of the GDR - categorized these as "domestic" rather than "international," in this context continuing its pre-1972 practice of denying the legitimacy of that state. Id. at 18.

42. "Indirectly" because as the following text explains, the two original validation laws were specifically declared inapplicable to prewar debt issues stemming from what, after 1945, were "East German" issuers. See Treaty on the Establishment of German Unity, Fed. Republic Ger.-Ger. Democratic Republic, art. 8, Aug. 31, 1990, 30 I.L.M. 457 [hereinafter Unification Treaty] and its Annex I, supra note 28, items 2, 9 and 10. The separate story of the murky history and eventual fate of claims of "East German" holders for payment of either "West" or "East" issues has not been cleared up by later researchers. See especially the effort of SAYATZ, supra note 19. Searches in the relevant court records of Berlin, Cologne, Frankfurt, and Munich disclosed a few docket entries of claims, but these do not identify the denominations, issuers, or holders. The decisions themselves were not archived, and court and archive officials reported that these records no longer exist.

43. Unification Treaty, supra note 43.

44. Stern, supra note 28 , at 376. 
eligibility problem should be noted. While instruments issued by bodies that had been located in the territory of what had become the German Democratic Republic could not be presented in the pre-unification era to the Federal Republic authorities, another narrow channel was available to US holders of these instruments. It arose as one of several compensation plans involving states that had expropriated ${ }^{45}$ the property of United States subjects in the aftermath of World War II. ${ }^{46}$ These persons, if US subjects at the time of that expropriation, could present claims to the US Foreign Claims Settlement Commission for certification, with eventual payment to be made following any later treaty-based settlement of reciprocal claims of the involved country and the United States. ${ }^{47}$ That approach had its own peculiarities and problems when it was created for claims against the German Democratic Republic, and those issues are reviewed below. But to revisit them and the larger East German issuer/holder problems in context, a brief discussion of the US litigation of the past decade is essential.

\section{THE CURRENT CONTEXT AND ITS EVALUATION}

\section{A. The Mortimer Decision ${ }^{48}$}

The Mortimer claims presented a variegated and complex set of issues that the court had to consider under both choice-of-laws principles and doctrines derived from public international law. These issues included the jurisdictional immunity of the foreign sovereign state, the liability of the state as successor to these Weimar-era entities, the applicable statutes of limitations in both their substantive and choice-of-laws aspects, and the well-known problem of repudiation of gold and other indexation clauses. ${ }^{49}$ It is to these issues and to their disposition in the only recently concluded US litigation that the following analysis turns.

Mortimer had not submitted these bonds for validation under either the German procedure (which had been extended beyond its original expiration debts.

45. Or, as in the case of the German Democratic Republic, repudiated any duty to pay earlier

46. See generally Richard B. Lillich \& BuRns H. Weston, InTERnational Claims: Their Settlement By Lump Sum AgreEments Part I: The Commentary (1975); Richard B. LiLlich \& Burns H. Weston, International Claims: Their SetTlement by Lump Sum Agreements Part II: The Agreements (1975); Burns H. Weston et Al., International Claims: Their SETTLEMENT BY LUMP SUM AGREEMENTS 1975-1995 (1999).

47. See Title VI of the International Claims Settlement Act of 1949, Pub. L. No. 94-542, 90 Stat. 2509 (codified as amended at 22 U.S.C. $\$ 1644$ (1976)).

48. Mortimer Off Shore Servs., Ltd. v. Fed. Republic of Ger., 615 F.3d 97 (2d Cir. 2010), cert. denied, 562 U.S. 1249 (2011).

49. $I d$. at $103-07$. 
date by later decree) or under the alternative US-based process based on the LDA. $^{50}$ Nor did it provide an explanation for its failure to do so-which might have entitled its late claims to consideration. ${ }^{51}$ These explanations, being relevant to the German treatment of late claims, might thus have been relevant under private international law principles in the US litigation. Instead, the court relied on a different section of the German statute, one that speaks to the rights of those bondholders who had refused the settlement offer of the London Debt Agreement. ${ }^{52}$ That section, however, while leaving the door open to later consideration of their claims once those accepting the arrangement had been paid, did not excuse these "nonassenters" from the statutory validation requirements. ${ }^{53}$ Only those who had (timely) submitted their holdings to that process were even eligible to have them considered at that later date, when holders who had accepted the deferred and adjusted payouts of the LDA arrangement could no longer be prejudiced by consideration of the non-assenters' claims. ${ }^{54}$

The reason why the Mortimer bonds were subject to the validation process in the first place rests on a specific feature of this issuer consortium. As earlier mentioned, the claim was based on dollar-denominated bearer bonds issued in 1928 by an umbrella organization of governmental banks, the Deutsche Landesbankenzentrale AG, under the designation "German Provincial and Communal Banks Consolidated Agricultural Loan-Secured Sinking Fund Gold Bonds Series A.. ${ }^{55}$ The individual banks within this issuer consortium were incorporated in what later were both Federal Republic and German Democratic Republic localities. ${ }^{56}$ Because of that particular situation, this debt issue was among those identified in the appendix to the Federal Republic's validation statute as permitting (and thus in essence requiring) submission to that process despite the fact that some of its members were "East German;" i.e., as individual issuers would not have been within the reach of the statute. ${ }^{57}$

As just pointed out, the German Unification Treaty and accompanying statutes did not carry the original validation legislation of the Western Occupation Powers and the Federal Republic forward to cover these "East

50. Id. at 114 .

51. $I d$.

52. $I d$. at $114-17$.

53. Id. at 117 .

54. Id.

55. $I d$. at 99 .

56. Id.

57. Id. at 109 
German" instruments; ${ }^{58}$ nor, as also indicated, did the LDA arrangement extend to them. The German decision discussed in Mortimer applied only to the bonds ascribable to those members of the umbrella organization based in what later was the territory of the Federal Republic. ${ }^{59}$ Thus, any filtering process applicable to "purely" East German bonds had to rely on other bases. ${ }^{60}$

One doctrinal basis, in fact used in one US decision, rests on another provision of the Validation Law requiring instruments of a single issuing entity that both before and after unification was situated at least in part within the boundaries of the Federal Republic to submit to the validation process. ${ }^{61}$ Many privately owned entities headquartered in what became East German territory had assets in the Federal Republic. In the context of

58. For details, see Welter, Commentary to $\S 367$, in MÜNCHENER KOMMENTAR ZUM HANDElSGESETZBUCH sec. 25 ( 2 d ed. 2009). Citing SAYATZ, supra note 19, Welter points out that at least the old instruments denominated in Reichsmark thus were not invalidated - at least at this point-in consequence of the earlier screening legislation. The RM instruments were, however, later voided (in the same manner old "Western" ones earlier were voided) by new legislation that then required their bearer to make an individual application demonstrating legitimate ownership. Even this legislation, however, did not apply in full severity to foreign-currency denominated instruments, whose holders under the applicable 1994 statute (Entschädigungs- und Ausgleichsleistungsgesetz, Sept. 27, 1994, BGBL. I at 2624) could for some time after unification claim a hardship exception to toll the otherwise applicable prescription rules. See SAYATZ, supra note 19, at 193; and, for his views on the questionable constitutionality of this effort at closure, see id. at 184 .

59. The other category of bonds - GDR bonds avant la lettre - might have been similarly handled, although the applicability of the original validation procedure after the 1990 unification turns out to be a question of Ptolemaic complexity under both German law and US choice-of-laws norms. See Hermann-Josef Brodesser, Wiedergutmachung und Kriegsliquidation $183 \mathrm{ff}$ (2000).

60. Welter, supra note 59 , states (my translation):

It is worth pointing out that foreign-currency denominated instruments of East German issuers, the wartime turbulence and their dubious value during the period of the GDR's existence, retained their character as debt instruments and their trading capacity. They could and still can be acquired in good faith and still maintain their function [to legitimate the rights inherent therein]. Because of the expropriation of private issuers in the Soviet Zone of Occupation and the GDR, this concerns interwar-period issuances of regional public bodies.

61. See Kupfer v. Fed. Republic of Germany, No. 07 Civ. 8589 (PAC), 2011 WL 1672741, at *3-4 (S.D.N.Y. May 2, 2011), which provides a bit more detail:

Where a bond has multiple issuers, Article 73 of the Validation Law specifies that the jurisdiction of the bond is determined by the seat of the designated examining agency. The bonds in question are clearly "West German." As such, Kupfer's argument that, even if the West German portion of the bond is subject to the Validation Law, the East German portion is not, is unavailing. Regardless of the percentage of the debt attributable to the East German banks, the bonds at issue are subject to the Validation Law because the examining agency was located in West Germany.

Of course, this rationale would not apply to instruments issued by an entity at the time located solely in what became the German Democratic Republic. 
resolving claims by creditors against those assets, under the unique legal doctrine of the Spaltgesellschaft ${ }^{62}$ - the doctrine allowing the West German facilities to be recognized as a separate legal entity-the GDR refusal to recognize any liability for the debts of the original entity after its liquidation and the transfer of its East German assets to the state was consistently treated as a concealed factual expropriation. A 1960 US-Federal Republic of Germany treaty extending the settlement obligations of the LDA to a small set of bonds issued by "East German" entities was based on this concept. ${ }^{63}$ This approach was not applicable in Mortimer, however, since as the decision pointed out, the consortial issue held by plaintiff did not fit this definition (of course, since that issue was, for other already mentioned reasons, eligible but had not been presented for validation, this was a moot point). ${ }^{64}$

Had the Mortimer opinion stayed with this evaluation, the analysis would have been less tortured. The mixed consortial bonds were subject to the Validation Law and eligible to participate in the LDA settlement; they had not been validated; the validation was necessary to preserve the right of these irredentists to resubmit their claims at least in 2010 if not already in 1990; not having taken advantage of what would have been a tolling of the statute of limitations their claim now was prescribed; and that would have been the end of the matter. Instead, the opinion unnecessarily split the consortial bonds into two subsets based on their individual members' East and West domiciles. ${ }^{65}$ It thus had to resolve both the limitations and the successor-liability questions that claimants who had not been eligible for the processes provided by the Federal Republic before unification had to face in

62. For a succinct description of this imaginative if result-oriented doctrinal invention, see Stephan Rammeloo, Corporations in Private InTERnational LaW 180 (2001). Refusal to recognize these debts of course was only one aspect in this context. The principal role of the Spaltgesellschaft was to allow former owners of an East German enterprise who had moved to the West to claim both physical and often intellectual properties located there in order to continue its activities. The most comprehensive study of all these issues is that of Bernhard Großfeld, Internationales Gesellschaft Chs. VII-XIII (Vol. 7, J. von Staudingers Kommentar zum Bürgerlichen Gesetzbuch mit Einführungsgesetz und Nebengesetzen, 1998). See also Abbo Junker, Spaltgesellschaften im deutschen Internationalen Enteignungsrecht, in Der Weg zur deutschen Rechtseinheit (Erik Jayme \& Oliver Furtak, eds., 1991). The special case of non-repayment of debt is covered by the short but finely taxonomic study of Gerhard Kegel, Probleme des internationalen Enteignungs- und Währungsrechts (1956).

63. See Second Agreement between the United States of America and the Federal Republic of Germany Regarding Certain Matters Arising from the Validation of German Dollar Bonds, Fed. Republic Ger.-U.S., art. 1, Aug. 16, 1960, 12 U.S.T. 944. The seven issuers included within the obligation either were Spaltgesellschaften with significant assets in the Federal Republic or with West German parent companies that had guaranteed these issues. Id. at sched. to art. $1, \boldsymbol{\mathbb { q }} 1$.

64. Mortimer Off Shore Servs., Ltd. v. Fed. Republic of Germany, 615 F.3d 97, 102-03 (2d Cir. 2010), cert. denied, 562 U.S. 1249 (2011).

65. Id. at 106-10. 
the post-1990 era for which validation legislation no longer existed.

That approach led the court into a dubious but dispositive use of foreign sovereign immunity through the use of a choice-of-laws analysis of the liability of the successor governmental entities for these Weimar-era debts of their predecessors. ${ }^{66}$ The German government's claim of jurisdictional immunity was denied as to the "West German" category of bonds, ${ }^{67}$ based on the court's holding that the FSIA's commercial-activity exception applied to these transactions. This threshold ruling thus led to the analysis of the validation process and ultimately to dismissal of these claims, as previously discussed. The claim based on the "East German" category of bonds, however, did not get past the jurisdictional gate.

The court's ruling on that issue is short enough to justify quotation:

While we have our misgivings as to whether successor state liability is even applicable in this case, we need not reach that question. Even if we were to find successor state liability, Mortimer's cause of action would nevertheless not lie because it would fail to allege an 'action ... based upon a commercial activity.' Accession to liability by the rules of customary international law entails no action by the successor state with respect to the commercial activity at issue - the assumption of liability. ${ }^{68}$ The state performs no action when it automatically assumes liability. This stands in sharp contrast to a country's assumption of liability through an explicit act, such as West Germany did here.

As for acts that the plaintiff argued did demonstrate an affirmative assumption of liability had been made, the best case for this argument was based on article 25 of the London Debt Agreement calling for the postreunification review of the LDA to make its provisions "applicable to the debts of persons residing in [East Germany]."70 To this the court simply

66. Id. at 105 .

67. For another recent case denying the Federal Republic's claim of foreign sovereign immunity in the same context, see World Holdings, LLC v. Fed. Republic of Germany, 613 F.3d 1310, 1317 (11th Cir. 2010). On the merits, however, this case raises yet other issues, discussed below.

68. Professor Roger Alford, who notes that he also appeared as amicus curiae in support of plaintiff in Mortimer, argues that this quoted approach ignores the original commercial activity FSIA-exception involved in the prewar issuance of these bonds. Roger Alford, Second Circuit Gives Successor States a Blank Slate on Credit Obligations, OPINIO JURIS (Aug. 23, 2010, 6:33 PM), http://opiniojuris.org/2010/08/23/second-circuit-gives-successor-states-a-blank-slate-on-creditobligations/. In my view, this conclusion, even if itself correct, cannot be extricated from the question of state succession, as the following discussion suggests.

69. Mortimer Off Shore Servs., Ltd., 615 F.3d at 109-110 (internal citations omitted). Of course, it bears recalling that these were not debts incurred by the German Democratic Republic, but Weimar-era debts of German public bodies that during the postwar division were part of the GDR.

70. Agreement on German External Debts, U.S.-United Kingdom, art. 25, Feb. 27, 1953, 4 U.S.T. 443. This referred to the issuers, not the holders. As earlier mentioned, GDR subjects who held prewar national or "West German" bonds were entitled to apply for a validation certificate and 
responded:

Although anticipating West and East Germany's reunification and the need to 'mak[e] equitable adjustments,' respecting debts incurred in the territory of East Germany... Article 25 and the remainder of the Accord refrained from delineating those possible adjustments, let alone imposing liability upon West Germany for any of East Germany's debts. ${ }^{71}$

In a sense, then, the state-succession question was treated as following the sovereign-immunity question. The court's further discussion of succession, however, turned the sequence around and in essence made sovereign immunity rest on the resolution of the succession issue. ${ }^{72}$ That is apparent from a second argument brought forward by the claimants, which tried to recharacterize the claim as one against the Federal Republic. ${ }^{73}$

That claim, presented as a second major basis for the argument of express succession to these obligations, was based on article 23(6) of the Unification Treaty, which provided that the FRG "shall take over the sureties, guarantees and warranties assumed by [East Germany] and debited to its state budget prior to unification." 74 This basis was rejected in Mortimer because the underlying premise, namely, that the German Democratic Republic itself first had accepted successor liability for bonds issued by governmental or private entities based in what became its territory, was deemed and in fact was wrong. ${ }^{75}$ Though the court itself did not raise the point, the GDR had at the least never accepted, and in some only partly distinguishable situations indeed expressly repudiated these prewar debts.

The larger issue, however, briefly discussed but not fully developed in

were eligible to join in the LDA settlement offers. See the official, if retrospective, statement to this effect by the FEDERAl OfFice for Central SERVices and UnResolved Property Issues [Bundesamt FÜr ZENTRALE Dienste UND OFFENE VermögENSFRAGEN (BADV)], http://www.badv.bund.de/DE/OffeneVermoegensfragen/Wertpapiere/Auslandsschulden/start.html

(last visited Oct. 17, 2016). If their instruments, as was often the case, had been deposited with East German financial institutions, however, these institutions soon were prohibited from delivering them to their owners. Thus it is likely that the majority of these holders were not, before 1990, in a position even to enter the validation process.

71. Mortimer Off Shore Servs., Ltd., 615 F.3d at 112 (internal citation omitted). A different plaintiff who filed an identical complaint in that same action first gained a deferral pending further briefing of its argument that a 1938 guarantee of a set of bonds issued by the State of Prussia (i.e., the predecessor to parts of the GDR) made the GDR liable under the commercial-activity exception. After briefing, however, the court rejected this basis for suit and dismissed the complaint. See Mortimer Off Shore Servs., Ltd. v. Fed. Republic of Germany, No. 10-11551-RWZ, 2012 WL 3600840 at $* 1-3$ (D. Mass. Aug. 21, 2012).

72. Id. at $105-06$.

73. $I d$. at $104-06$.

74. Id. at 103 (quoting Unification Treaty, supra note 43, at 479 (alteration not in original)).

75. Id. at 109. 
Mortimer, is the unusual, though not unique, definition of state succession the German courts consistently have maintained concerning the unified German state's responsibilities for any prewar obligations of public entities located (postwar) within the boundaries of the former German Democratic Republic. While any discussion of that larger issue moves into territory that extends beyond this litigation and into a broader realm of public international law, it is worth visiting if only because a large number of statesuccession disputes of course do involve financial obligations of predecessor regimes.

\section{B. State Succession and the Post-Unification Federal Republic}

The case most closely on point involved thirty-year gold-protected dollar-denominated bonds issued in 1925 by the City of Dresden (an "East German" issuer in our context), three-fourths of which had been placed in the United States; the Federal Court of Justice rejected the holder's claim on the ground that the current City of Dresden, whose legal identity had been eliminated as part of the GDR's original communal reorganization, was not the legal equivalent of the prewar issuer; nor did the municipal reorganization accompanying the 1990 reunification reestablish that legal continuity. ${ }^{76}$ In addition, the 1930 conversion of Dresden's municipal operation of the utilities, to which the proceeds of the issue had flowed, into a private-law corporation left the city at most with a repayment obligation towards that corporation but not with a direct obligation towards the bondholders.

Finally, as if these considerations did not suffice, the four-year limitations period for each interest coupon (1934-1945 in this case) and even the thirty-year period from the time of maturity of the original bond issue in 1945 (i.e., to 1975) had run. Lest the reader wonder about any possible tolling for the period after 1945, during which East German law precluded any recourse, the court ruled in lapidary fashion that this was not the responsibility of the municipality. The harshness of this conclusion was substantially mitigated, however, by the court's acceptance of the possibility of a timely complaint, had one been filed in the years immediately following unification. Here the jurisprudence concerning a possible "equitable" factspecific exception and its grounding in commercially reasonable and honorable (redlich) behavior was applicable; but an 11-year delay in bringing the action could not even under that jurisprudence be deemed to fall within this exception.

76. Bundesgerichtshof [BGH] [Federal Court of Justice], Oct. 25, 2005, 164 BGHZ 361, 369f. 


\section{The Role of Private International Law}

An interesting second problem, and the one with which the parties in Mortimer did indeed engage intensively, involved the choice-of-laws for these prescription questions. In Dresden, the BGH had applied German law on the intriguing ground that under the law of the time neither a state nor a public municipality "wanted" to submit itself to any law other than its own. It recognized that the bond's acceptance of New York as a place of payment, the use of the dollar as the measure and medium of payment, and the bond's formulation of the loan conditions were weighty indications in favor of an implied submission to "US" law. Objectively viewed, however, these indicia were held by the court to be relevant only to the payment transactions themselves, not to the substance of the claim; indeed, the bond's specific formulation that all acts relevant for the validity of the obligation had been taken pursuant to the constitution and laws of the German Reich was taken to support this view.

The resulting depeçage, the court further found, was possible and permissible under the law of the time of issue. In support of this holding, the BGH cited the (at the time) famous Serbian and Brazilian Loan Cases decision of the Permanent Court of International Justice. ${ }^{77}$ If anything, however, that well-known decision stood for the converse of the conclusion reached by the BGH. While the PCIJ agreed that different choice-of-laws considerations might apply to different aspects of this kind of dispute, ${ }^{78}$ that conclusion permitted the PCIJ to apply the law of the place of payment; namely, the French law that, as to international loans, preserved the validity of gold clauses (though invalidating them when used in domestic contracts). ${ }^{79}$ This approach thus preserved the right of the bondholders to demand payment in "gold francs," a matter the chosen Serbian law apparently did not address (and thus might have prohibited). ${ }^{80}$ The German court's approach, purportedly based on this case, permitted the opposite outcome, since it accepted the application of the US prohibition to these

77. Case Concerning the Payment of Various Serbian Loans Issued in France (France v. Kingdom of the Serbs, Croats and Slovenes), Judgment 1929 P.C.I.J. (ser. A) No. 20 (July 12).

78. Id. at 40-44. The distinction which seems indicated for the purposes of this case is more particularly that between the substance of the debt and certain methods for the payment thereof.

79. Id. at 44. The case is authoritatively explained and criticized in ARTHUR NUSSBAUM, MONEY IN THE LAW NATIONAL AND INTERNATIONAL: A COMPARATIVE STUDY IN THE BORDERLINE OF LAW AND ECONOMICS 417-19 (rev. ed., 1950). It also is the foundation for a sophisticated review of the drafting specificities driving these international conflict-of-laws decisions by three international-bond experts; see Sommers, supra note 10.

80. More specifically, NussBaum, supra note 80 , at 427 , points out that the Serbian and Brazilian governments did not plead such invalidity, so that "the outcome ... would have been the same, namely, to hold the debtor governments liable for the full gold value." 
value-maintenance clauses. ${ }^{81}$

Speaking perhaps too generally, it does seem clear from the tortured grappling with these issues in the primary and secondary publications of the time that the public interest in removing the sword of the gold clause and its kin was too important - at least in the courts of the many countries facing similar financial troubles - to be left to refined applications of possible alternatives derived from doctrines of private international law. ${ }^{82}$

As to the issue of prescription as a choice-of-laws matter, the Mortimer opinion basically ignored it, since it viewed the succession issue-still to be further discussed-as dispositive. The recent World Holdings decision, ${ }^{83}$ however, did delve into that issue, leading it first to the choice of the New York law of limitations. It followed that march up the hill back down, however, by looking to the guarantee provisions of the bond instrument and their legal consequences under German law in order then to choose the shorter of two potentially applicable New York statutes of limitation-the one that had run by the time the plaintiff's suit had been filed. ${ }^{84}$

\section{The Role of Public International Law and Policy}

The plaintiff in World Holdings, as earlier mentioned, also presented some bonds that allegedly had been validated. ${ }^{85}$ That led the Court to public international law by way of a detailed and indeed important disquisition on a major issue of treaty interpretation. This inquiry became the dispositive point on the statute of limitations issue and thus does justify a more detailed evaluation here. That evaluation begins with Article 10 of the London Debt

81. In fact, a more respectable approach leading to a similar conclusion was available from the Scandinavian and Finnish pre-World War II jurisprudence involving the analogous fact situation; namely, recourse to the law of the currency rather than the law of the place of issuance, when the former-after issuance of the instruments - abrogated gold-clause or similar protection. See Henrik Bahr, The Norwegian Gold Clause Case, 12 AM. J. ComP. L. 1, 6-20 (1963).

82. The most persuasive testimony to this effect remains the magisterial work of NUSSBAUM, supra note 80 , especially at 429,443 .

83. World Holdings, LLC v. Fed. Republic of Germany, 794 F. Supp. 2d 1341 (S.D. Fla. 2011). The Court first ruled, in my view appropriately, that the Federal Republic was not a "person" in the context of the six-year prescription for actions on a bond issued or guaranteed by "any person ... and secured only by a pledge of the faith and credit of the issuer ...." Id. at 1348-49. It then pointed to the revenue streams these bonds were assigned to enable their servicing, as well as their characterization under German law, in order to conclude after equally exquisite analysis that these rights went beyond a mere full-faith-and-credit pledge and thus could justify use of the sixyear provision. All of this (and more, which I omit) turned out to be obiter dicta only, however, as the Court also recognized that even the 20 -year statute had run by the time of the filing of the suit. Id. at $1348-51$.

84. Id. at $1348-51$.

85. Id. at 1343-44. The German government disputed this fact but the resolution of the disagreement was unnecessary given the Court's disposition. Id. 
Agreement, which in intent and effect put pressure on private holders of prewar German debt instruments to accept the settlement hammered out by the negotiating parties. It did so by precluding any payment to nonassenting creditors "until the discharge or extinction of all obligations under the present Agreement." ${ }^{, 86}$ Since those obligations, as we have seen, ran until 2010, the present actions clearly would have been timely filed-if the quoted provision applied.

But Article 10 continued:

This provision does not apply to debts arising from marketable securities payable in a creditor country.

The presented claims fit that description. Nonetheless, it was apparent, and the plaintiffs provided a number of contemporaneous statements so demonstrating, that even semi-official descriptions of the procedures to be followed ignored that sentence and either assumed or explicitly stated that no claim of a non-assenting bondholder could be paid until the conclusion of the payments to assenting creditors. That reading suggests though it does not compel a tolling conclusion. ${ }^{88}$ The World Holdings court, however, while acknowledging that the "official" Meeting Minutes of the Conference proceedings could be consulted in case of a dispute of interpretation of the treaty text, simply concluded, without significant analysis, that there was no dispute as to the meaning of the sentence. ${ }^{89}$ Hence no argument relating to tolling could be made, and under the Court's analysis the prescription period began to run in 1964 when the Dawes Bonds reached maturity and in 1965 when the Young Bonds did. ${ }^{90}$

This deserves further analysis. It is apparent, of course, that the availability of an exit through a functioning secondary market offered these bondholders the opportunity to receive payment immediately. So far as US secondary markets were concerned, however, the SEC had prohibited any trading in these securities some years earlier (for reasons already discussed

86. Agreement on German External Debts, U.S.-United Kingdom, art. 10, Feb. 27, 1953, 4 U.S.T. 443 [hereinafter London Debt Agreement]. The contrast with the failed unilateral effort of the Argentine government to pressure holders of its state obligations through similar strategies is worth noting. See NML Capital, Ltd. v. Republic of Argentina, 727 F.3d 230, 237 (2d Cir. 2013).

87. London Debt Agreement, supra note 87.

88. "Does not compel" in the sense that the liquidity available through such secondary markets was a contemporaneous substitute for acquiescence in the settlement scheme (but at what discount relative to that of this arrangement?), and thus could justify the simultaneous running of the applicable statute of limitations.

89. World Holdings, LLC v. Fed. Republic of Germany, 794 F. Supp. 2d 1341, 1345-48 (S.D. Fla. 2011).

90. Id. at 1348 . 
and having to do with the potentially dubious nature and ownership of these instruments). ${ }^{91}$ That prohibition was not lifted until after a number of agreements and statutes implementing the LDA were promulgated; even then, of course, the question of validation had to be faced by those holders choosing to accept immediate payment at whatever discounted valuation existed on those markets. Under these circumstances, the question of prescription and its tolling was more nuanced than the court indicated. In the end, however, it probably is reasonable to argue that since trading in "East German" bonds was not absolutely prohibited in these markets, ${ }^{92}$ not to mention in less regulated Swiss and other European secondary markets, notice of some prescription risk was given by this element of LDA article 10.

This focus on public international law also justifies a return to the broader issue of state succession, since the question, whether a forum state need honor another state's constitutional or administrative law view of state succession, is not clear-cut. The Mortimer opinion did consider this matter briefly, and concluded that neither customary nor conventional norms of public international law were dispositive; it therefore basically accepted the German municipal law on the matter. ${ }^{93}$ This issue, too, deserves a bit more comment.

While for the first thirty years after World War II the Federal Republic always claimed to be the exclusive successor to the prewar state, it made one important exception in the context of the already discussed London Debt Agreement. Without using its only partial territorial control in a direct legal sense to justify the distinctions there negotiated, it did use that reality to exclude from the settlements provided in that Agreement the prewar obligations of those sub-state governmental divisions now outside its

91. See Trading In German Securities and Adoption of Rule X-15C2-3. Under the Securities and Exchange Act of 1934, Exchange Act Release No. 34,4983, 1954 WL 5776, *1 (Jan. 11, 1954), which terminated the wartime suspension of trading in German (and other Axis) securities for those bonds of German private- and public-sector issuers that passed through the new validation procedures. The Release provides considerable background information, and goes on to make the following declaration:

The Commission has no information when validation procedures will be established for dollar securities of issuers in that part of Germany under the control of the Soviet or Polish Governments. Therefore, the Commission ... . requests that brokers and dealers continue to abstain from any activities which would tend to create a public market in these securities.

Id. at *3.

92. In two senses: the SEC only "request[ed]" brokers and dealers not to make a public market; and at least with US recognition of the GDR in 1971, trading from then on might have generated some renewed though diminished liquidity. Id.

93. Mortimer Off Shore Servs., Ltd. v. Fed. Republic of Germany, 615 F.3d 97, 109-14 (2d Cir. 2010), cert. denied, 562 U.S. 1249 (2011). 
control. With unification, however, that situation had to be faced. Succession to the obligations of the Weimar Republic's obligations was not the problem; we have seen that those (and those of Prussia) had been accepted as the responsibility of the Federal Republic from the beginning. The problem was succession at the provincial, communal and public agency levels. ${ }^{94}$ Those became the subject of a major Chapter of the Unification Treaty between the Federal and the German Democratic Republic.

\section{The Post-Unification Administrative-Law Framework}

Three articles of the Treaty were central to the question. ${ }^{95}$ Article 21 concerned those assets (perhaps better, properties) of the GDR that directly related to governmental services, and converted these to federal assets; those related to Länder, communal and other agencies' services were transferred to those bodies that after unification were charged with providing these services. ${ }^{96}$ Article 22 dealt with financial assets of these various GDR bodies. $^{97}$ They were transferred to the Federal Government in a trustee capacity; $50 \%$ thereof to remain with it but to be used in support of its public missions in the new Länder. The other half, which went directly to the Länder pursuant to a population-based formula, was to be available also to those units' communal organizations.

Critical, of course, was the question of succession to the obligations of these Länder, communal and agency bodies. This was regulated in Article 23 of the Treaty. It is both complex and well illuminates the microsurgery that rejoined these two German bodies politic. For present purposes the following paraphrase will suffice: The overall debt of the GDR financial household was accepted into a "special property fund" (Sondervermögen), a unit without separate legal capacity but for whose obligations the Federal Republic was liable. ${ }^{98}$ This unit was permitted to borrow funds for the purpose of meeting these transferred obligations and was to function until

94. In contrast, the liability of postwar "West German" municipalities was never challenged on this ground of succession once the LDA had included them in its scope. See Lively Ltd. v. City of Munich, [1976] 1 W.L.R. 1004 QB (resolving a dispute concerning the exchange rate to be applied given the unclear wording of LDA article 13).

95. The following distinction between assets directly devoted to governmental/administrative functions ("Verwaltungsvermögen") and assets that are not in service to specific administrative functions ("Finanzvermögen") reflects the traditional German categorization based on budgetary considerations. See, e.g., Hans-Jürgen Papier, Recht der öffentlichen Sachen, in VII ALlGEMEINES VerWALTUNGSRECHT (Hans-Uwe Erichsen \& Dirk Ehlers, eds., 14th ed., 2010). This "direct/indirect" distinction clearly drives the resolution of the successor-liability problems next discussed.

96. Unification Treaty, supra note 43 , at art. 21.

97. Id. at art. 22.

98. Id. at art. 23 . 
the end of $1993 .{ }^{99}$ Thereafter the federal and Länder governments were to carry any continuing obligations under a similar population-based formula. ${ }^{100}$

Which obligations were to be taken over was the key question. Paragraph (6) of Article 23 specified that as of the date of the GDR "entry" (Beitritt) into the Federal Republic, the latter would stand in its place for all GDR pre-unification guaranties, warranties and related covenants; half of this outlay was in turn to be repaid to the federal government by the new Länder under the same formula. ${ }^{101}$ But as the City of Dresden case demonstrates, there was less to this than meets the eye.

\section{The German Constitutional-Law Framework}

Finally, two sets of rulings involving constitutional and international law bear on this succession problem at least in analogical terms. The German Federal Constitutional Court ruled in 1999 that the statutory exclusion of a right of restitution of real property, wrongfully expropriated by the GDR, but later acquired by a private party in good faith [again, redlich], did not violate the equivalent of the due process and equal protection norms of German constitutional law. ${ }^{102}$ And in a ruling concerning similar succession rights, claimed under the European Convention of Human Rights, the European Court of Human Rights also held against the original owner. ${ }^{103}$

\section{The Reception of the German Approach in the International Law Framework}

Although this is not the place for a general discourse on the principles of customary or conventional public international law relevant to the issues of

99. Id.

100. Id.

101. Id. at art. 23 -6.

102. See Bundesverfassungsgericht [BVerfG] [Federal Constitutional Court], Nov. 23, 1999, 1 BVerfGE 1/94, http://www.bverfg.de/entscheidungen/fs19991123_1bvf000194.html. Of course, inlieu compensation was available, though the amount thereof occasioned yet further disputes; see Richard M. Buxbaum, The von Maltzan Case: Property Rights After Three Generations, in ZIVILUND WIRTSCHAFTSRECHT IM EUROPÄISCHEN UND GLOBALEN CONTEXT 291, 293 (FS Norbert Horn 2006).

103. Prince Hans-Adam II of Liechtenstein v. Germany, Application Instituting Proceedings, 2001 I.C.J. 1-32 (June 1), http://www.icj-cij.org/docket/files/123/7077.pdf. See also Case Concerning Certain Property (Liechtenstein v. Germany), Judgment, 2005 I.C.J. 25 (Feb. 10), http://www.icj-cij.org/docket/files/123/8234.pdf. 
state succession, ${ }^{104}$ in my opinion the core problem lies in the context of applying classic definitions of state succession to the specific case of the two postwar Germanys. Most modern state-succession issues concern states emerging out of a dissolving earlier state (e.g., the Austro-Hungarian Empire, the Soviet Union, the Yugoslav Federation) or states released by agreement or force of arms from dependent to independent entity status (e.g., Indonesia or Nigeria among many other cases of decolonization). ${ }^{105}$ At the other end of the spectrum lie states that continue unchanged from their previous incarnation after an interregnum created, typically, by an occupatio belli (e.g., Japan). The German case sits between these two types, and it is the interregnum itself-in this case one of forty-five years - that placed it in the first category, but only for that period. Once rejoined, it returns to the second category. No precedents exist in customary or conventional international law allowing for a definitive conclusion as to the ongoing obligations of the newly reconstituted German state, and thus as to the legitimacy of the Mortimer court's argument. This is a particularly difficult aspect of an already difficult general situation. As Koskenniemi succinctly puts it:

Doctrinal debate about treaty succession remains an intriguing play of rules and exceptions, presumptions and rebuttals... The 1978 Convention can be used to support a position of continuity as well as rupture depending on whether one chooses to apply its main rule or its exception and on how one wants to characterize the events.... Moreover ... it is always possible to oppose any rule it may seem to support by the point that custom in fact provides a different rule. ${ }^{106}$

104. The exhaustive and valuable study of D.P. O'Connell treats succession issues faced by the postwar Federal Republic of Germany but not the specific aspects of their bearing on the situation of the German Democratic Republic. D. P. O'ConNell, State Succession IN MUNICIPAL LAW AND INTERNATIONAL LAW, INTERNATIONAL RELATIONS VOL. I-II (1967). Two relatively recent treatments bring these discussions into the current era and its examples, but neither provides definitive conclusions on the specific issue of continuing responsibility for predecessor-state debts. See PATRICK Dumberry, State SuCCESSION TO INTERNATIONAL RESPONSIBILITY (2007) (focused largely on delictual responsibility) and TAI-HENG CHENG, StATE SuCCESSION AND COMMERCIAL OBLIGATIONS (2006). While the latter (whose author was on an amicus curiae brief on behalf of plaintiff in the Mortimer case) also discusses the Draft Vienna Convention on Succession of States in Respect of State Property, Archives and Debts of 1983, which has not come into force, his treatment is largely about the political aspects of the treaty-making process.

105. An issue not unknown in U.S. history. West Virginia (after litigation) accepted proportional responsibility for Virginia's antebellum bond issues following the states' separation. See the brief description in Brent Tarter, The Virginia Debt Controversy, EnCYClOPEDIA VIRGINIA, http://www.encyclopediavirginia.org/Debt_Controversy_The_Virginia\#itsTL (last visited Sept. 20, 2016).

106. Martti Koskenniemi, The Present State of Research Carried Out by the English-Speaking Section of the Centre for Studies and Research, in State SucCession: Codification Tested AGAINST THE FACTS 116 (1997). 
This clearly suggests the difficulty of determining whether the earlierquoted Mortimer sentence- - Accession to liability by the rules of customary international law entails no action by the successor state with respect to the commercial activity at issue - the assumption of liability" - is correct or not. $^{107}$

As if that were not enough, an additional complication the German history presents has to do with a state's internal status within a federal system. Again, without going into a full-scale discussion of that question, a brief contextual comment is useful. Norms of public international law addressing foreign sovereign jurisdictional immunity distinguish subordinate political units of the state from the state itself, but the consequences of that distinction are not uniformly agreed upon. Indeed, the U.N. committee drafting the Articles on the Jurisdictional Immunities of States became engaged in an "intense debate regarding whether immunity should be extended to political subdivisions... by reason of their entitlement to exercise sovereign authority, or by reason of their actual performance of such acts." ${ }^{108}$ Article 2(1)(b)(ii) of the finally adopted Draft text of 2004 specifies what seems to be the consensus; namely, that the term "State" includes "constituent units of a federal State or political subdivisions of the State, which are entitled to perform acts in the exercise of sovereign authority, and are acting in that capacity." 109 The U.S. statute includes "political subdivisions" within the definition of "foreign state"110 and is understood to cover the state of a federal system; but not more subordinate units such as municipalities. The pre-statutory jurisprudence was inconsistent, ${ }^{111}$ suggesting that in the case of federal states the concept of "political subdivision" itself was to some degree open to varying interpretations.

107. Mortimer Off Shore Servs., Ltd. v. Fed. Republic of Germany, 615 F.3d 97, 110 (2d Cir. 2010), cert. denied, 562 U.S. 1249 (2011). The interwar problems of state succession are fully discussed in ERnst H. Feilchenfeld, Public DebTs and State Succession 506-622 (1931); a wider if of necessity more cursory overview of the many state-debt default situations with useful event-contextualized analyses is that of M.H. Hoeflich, Through a Glass Darkly: Reflections Upon the History of the International Law of Public Debt in Connection with State Succession, 1982 U. ILL. L. REV. 39, 60-69 (1982).

108. HaZel Fox, The LaW of State IMmunity 331 (2002).

109. G.A. Res. 59/38, Convention on Jurisdictional Immunities of States and Their Property (Dec. 2, 2004), http://www.un.org/en/ga/search/view_doc.asp?symbol=A/RES/59/38. It is not yet in force for lack of (30) ratifications. Of the OECD member states only 12 have ratified it, only one (Switzerland) a federal state; Germany and the United States have not even signed it. See http://www.wipo.int/wipolex/en/other treaties/parties.jsp?treaty id=259\&group id=22.

110. 28 U.S.C.A. § 1603(a) (West 2006).

111. Compare Sullivan v. State of Sao Paulo, 122 F.2d 355 (2d Cir. 1941), aff'g 36 F. Supp. 503 (E.D.N.Y. Jan. 9, 1941), with Molina v. Comision Reguladora del Mercado de Henequen, 104 A. 450 (N.J. July 17, 1918). 
In the present context, this suggests that while a hypothetical City of Dresden ${ }^{112}$ could not have claimed sovereign immunity in a Mortimer setting, an equally hypothetical State of Saxony might have. This distinction leads to a recursive loop, however, as to the responsibility of the ultimate state sovereign, even when considered only as a matter of interstate political relations if not as a matter of personal jurisdiction. Thus Fox continues:

Differences have also surfaced as to whether the nature of constituent units of a federal State requires their recognition as a separate category, and the extent to which a claim against a State enterprise with segregated property [but including] "a political subdivision" as well] affects the immunity of the State itself and its central funds. ${ }^{11}$

In short, it well may be that the constitutional regime of that higher sovereign cannot alone suffice to dismiss the demand of a foreign state on behalf of its subject-creditors for payment of at least the Saxony (state) if not the Dresden (city) debts, ${ }^{114}$ whether or not the parent state of these subdivisions had pledged its full faith and credit in support of their former incarnations' debts. ${ }^{115}$ Of course, the rejection of the commercial-activity exception in Mortimer, as it bears on Germany's obligations in the context of the "East German" bond issues, whether defensible or not, may have ended that private-litigation path to redress. ${ }^{116}$ It does not end the matter in terms of international relations. On the other hand, whether the context in which these claims have shown up deserves the benign support of the claimants' state is a totally different matter, one that will be considered in Part V below. 1925

112. "Hypothetical" in the sense of a posited legal continuity of the 2004 city with that of

113. Fox, supra note 109 , at 331.

114. That seems to have been the view of U.S. writers before World War II; see, e.g., James Wilford Garner, Questions of State Succession Raised by the German Annexation of Austria, 32 AM. J. INT'L L. 421, 427-30 (1938).

115. To go further and ask whether the form of Germany's unification by means of a formal treaty between two states matters to this account of successor obligation for predecessor debts would take us into increasingly fruitless lines of inquiry.

116. Mortimer Off Shore Servs., Ltd. v. Fed. Republic of Germany, 615 F.3d 97, 108-10 (2d Cir. 2010), cert. denied, 562 U.S. 1249 (2011). In other words, assuming a private action were brought in a U.S. court against a German Länder, the Mortimer analysis that led to the grant of jurisdictional immunity to Germany would presumably lead to the same outcome in favor of the Länder. The dispositive finding of a lack of explicit repudiation of "its" prewar debts by the German Democratic Republic undoubtedly fits the actions - or lack of actions - of any given postwar political subdivision thereof. 


\section{FOREIGN STATE SUCCESSION ISSUES AND THE U.S. FOREIGN ClAIMS SETTLEMENT COMMISSION}

For the sake of comprehensiveness one other process arising in a different context but raising some of these same issues should be briefly discussed. These issues of state succession also appeared before U.S. courts, and again in the context of liability for prewar debts. As earlier mentioned, ${ }^{117}$ a different channel had been available during the Cold War era for the presentation and payment in the United States of "East German" debt instruments. As it had in the case of other state-socialist expropriation events, the Congress legislated a process under the Foreign Claims Settlement Commission structure for the certification of claims by holders who already were U.S. nationals at the time of expropriation of their foreignheld property, certifications that would ripen into (usually partial) payment when and if the U.S. and that state entered into a treaty settling their respective claims. ${ }^{118}$

The first claim filed under this 1979 program involved bonds issued by the Aktiengesellschaft Sächsiche Werke (Saxon Public Works, Inc.), a Weimar-era entity incorporated under ordinary corporation law but owned by the State of Saxony. The claimant, Medoff, a U.S. subject, had not submitted the bonds for validation because this was not required for someone in her situation, in contrast with that of Abrey. ${ }^{119}$ The issue, rather, was whether under the applicable legislation an expropriation of these bonds had occurred-expropriation being a condition of eligibility to submit a claim for certification and later payment.

Earlier programs under legislation governing other states' expropriations had been interpreted to require an express repudiation by the expropriating government, following nationalization of former private-sector issuers, of the relevant debt instruments. Since express repudiation was not always demonstrable even when service and repayment of the debts of these nationalized enterprises had ceased, uncertainty had arisen about the eligibility of such claims. The cases finally congealed around the distinction between postwar GDR treatment of prewar private-sector and of prewar state-sector enterprises. In the case of the former, their nationalization and subsequent non-payment was treated as a de facto expropriation and express

117. See supra notes $46-48$ and accompanying text.

118. See LILLICH, supra note 47.

119. Abrey v. Reusch, 153 F. Supp. 337, 338-39 (S.D.N.Y. 1957). In re Medoff, Claim No.

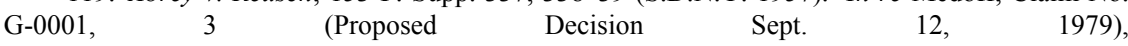
https://search.justice.gov/search?utf $8=\% \mathrm{E} 2 \% 9 \mathrm{C} \% 93 \&$ affiliate $=$ justice \&query $=$ German + Democratic + Republic + Medoff\&commit=Search. 
repudiation was not additionally required. ${ }^{120}$ These claims were certified. In the case of public-sector issuers, restructuring of their formal status within the new governmental architecture was deemed not to be an act of nationalization since these issuers already were state-owned. As a result, "mere failure to pay" was insufficient. An express later repudiation of their obligation to service prewar debts was required in order to render these claims eligible for certification, this repudiation being deemed the equivalent of a separate act of expropriation. Typically, however, no act of express repudiation occurred and so these claims were rejected.

In a different and later country context, that of Cuba, the authorizing legislation did expressly specify that failure to service the debts of an originally state-owned issuer of this sort would be compensable without an express repudiation. ${ }^{121}$ Why this language was inserted into the Cuban

120. Courts of the Federal Republic of course had dealt with many similar issues before the mutual recognition of the two states in 1971, and also in the context of expropriation. See the discussion of the Spaltgesellschaft, supra note 63 and accompanying text.

121. It is a subtle distinction. Compare the otherwise identical language of the GDR and the Cuban statutes' definitional provisions:

22 U.S.C.A. $\S 1643 a(3)$ (West 2004):

The term "property" means . . . debts owed by the Government of Cuba . . . or by enterprises which have been nationalized, expropriated, intervened, or taken by the Government of Cuba... and debts which are a charge on property which has been nationalized, expropriated, intervened, or taken by the Government of Cuba .... .

22 U.S.C.A. $\S 1644 a(3)$ (West 2004):

The term "property" means any ... debts owed by enterprises which have been nationalized, expropriated, or taken by the German Democratic Republic for which no restoration or no adequate compensation has been made to the former owners of such property.

A GDR-takings case, In re Jolan Munk, FCSC, Claim No. G-1732 (available in the Archives of the Foreign Claims Settlement Commission) provides the best description of this distinction:

Under Title $\mathrm{V}$ of the [Cuba] Act... the express language '... debts owned [sic] by the Government of Cuba ...' was included in the definition of the term property .... No such language was placed in Title VI of the Act, authorizing adjudication of claims against the German Democratic Republic.

It is therefore clear that neither the statutory language nor the legislative history ... indicates an intentionon the part of Congress that the Commission should ignore the clear rule of international law that the non-payment of debt obligations by a foreign government does not constitute a nationalization or other taking of property under international law.

Decision G-1732, Sep. 10, 1980, p. 2f. Compare In re Alicia Montalvo, Claim No. CU-1745, 3
Decision
$\begin{aligned} & \text { (Proposed } \\ & \text { https://www.justice.gov/sites/default/files/pages/attachments/2014/08/05/cu-1745.pdf, allowing the }\end{aligned}$


claims statute ${ }^{122}$ is something of a mystery, as the properties expropriated there typically had been privately owned. The post-expropriation failure to honor their debts to their foreign former owners would have sufficed as an expropriation under any version of the process; thus, their taking amounted to a compensable act in any event. ${ }^{123}$ Many of the GDR properties that figured in the German claims, however, had been owned by governmental units; there, in other words, the Cuban proviso would have had a significant effect.

This difference of treatment is even more puzzling when one considers the state-succession context. If, as previously concluded, ${ }^{124}$ customary norms of public international law do not obligate a successor state to assume the debts of a predecessor, it would be all the more necessary for a statute creating a claims process in a state-succession case to use a "Cuban" proviso. Otherwise those presenting a claim to their own state based on a foreign expropriation could not obtain access to the funds seized by that state to satisfy these claims - as indeed happened in this East German example. Perhaps the Congressional drafters of the GDR claims process statute simply were unfamiliar with the described problem of state succession and liability; alternatively, they may have accepted the exclusion of liability and thus of many of the claims from eligibility as a legitimate consequence of the relevant norms. ${ }^{125}$ The usual aids to legislative intent provide no help in this instance.

non-payment-of-interest claim in the Cuban context. This and all other adjudicated claims under the Cuba program may be found in the FCSC Report cited supra note 96.

122. Act of Oct. 16, 1964, Pub. L. No. 88-666, 78 Stat. 1110 (codified at 22 U.S.C.S. $\S \S$ 1643-1643m (1964) (amending "the International Claims Settlement Act of 1949 to provide for the determination of the amounts of claims of nationals of the United States against the Government of Cuba").

123. Given the recent recognition of Cuba, these matters presumably soon will be revisited. An early review of mutual claims of the two governments, sympathetic to a setoff argument, is that of Archibald R. M. Ritter, The Compensation Issue in Cuban-US Normalization: Who Compensates Whom, Why and How?, in CUBA IN THE InTERnAtional System 259 (A. Ritter \& J. Kirk, eds., 1995). According to the U.S. Foreign Claims Settlement Commission, certified claims total approximately $\$ 2$ billion before interest, which is set at six per cent from the time of the loss. See Foreign Claims SetTlement Commission, Completion of the Cuban Claims Program Under Title $\mathrm{V}$ of the International Claims Settlement Act of 1949, http://www.justice.gov/sites/default/files/fcsc/docs/final-report-cuba-1972.pdf (last visited Sept. 20, 2016).

124. See supra notes 88-96 and accompanying text.

125. The total reorganization of the Land, Agency and Municipal governmental structures by the German Democratic Republic created yet further complications concerning successor-entity responsibilities for debts of their geographically and functionally different predecessors, as the discussion in the City of Dresden case, Bundesgerichtshof [BGH] [Federal Court of Justice], Oct. 25, 2005, 164 BGHZ 361, and accompanying text, well demonstrates. 


\section{THE BONDS OF GERMAN CATHOLIC INSTITUTIONS}

The substantial financial issues with which the postwar players were engaged justified their efforts and this discussion. Running alongside the large story, however, is a saga of a rather peculiar sort. As mentioned at the outset, there was a fourth category of prewar debt instruments, the obligations of Catholic religious bodies ranging from the major archdioceses to remote and tiny monasteries, abbeys and schools. Approximately 300 separate bond issues emanated from this sector during the post-inflation 1920s, denominated in Dutch currency and placed in the Netherlands. In the aggregate they barely reached the level of one major city's single bond issue; for example, that of Munich or Berlin. What makes a discussion of this minor episode worthwhile is less their prewar than their wartime and thus postwar fate; namely, the fact that the German occupation of the Netherlands brought with it a coerced redemption/repayment scheme that could not withstand challenges to its validity after the war. That particularity justifies adding this separate chapter to the larger story. ${ }^{126}$

The various motivations for these issues no longer can be traced through these institutions' records; even the fairly extensive archival records of the larger bond issues by the major archdioceses do not illuminate that question. It is probable that the significant increase in Dutch institutional and personal savings, ${ }^{127}$ coupled with the almost total evaporation of the savings of the German population during the then-recent hyperinflation ${ }^{128}$ made what would have been the most obvious source of this kind of support unavailable. Finally, the fact that the Netherlands remained neutral during WWI, coupled with considerable pro-German sentiment among much of its population, made the appeal of German Catholic organization to their Dutch co-religionists understandable.

The use of the funds is less of a mystery. The consequences of the hyperinflation that depleted funds for repairs and reconstruction and the simple appeal of a ready marketplace all are likely explanations for these

126. See the listing in GlasemanN, supra note 10, at 124. Of course, some Reich and lowerunit public entity bonds, as well as private-sector bonds, also ended up with Dutch holders; indeed, the major issues, such as the Dawes Reparations Bonds, were issued in a number of foreign currencies, not least among them the Dutch. Thus to some degree the gulden issues experienced the same wartime treatment, if not the same postwar fate. Therefore, the following overlaps with this public-sector cohort as well.

127. See both for the amounts and the reasons for this expansion Jeroen Euwe, Amsterdam als Finanzzentrum für Deutschland, 1914-1931, in DEUTSCHLAND UND DIE NIEDERLANDE 153, 163 (Hein A.M. Klemann \& Friso Wielenga, eds., 2009).

128. See among the many studies of this subject Gerald D. Feldman, The Great Disorder: POlitics, ECONOMics, AND SOCIETY in THE GERMAN INFLATION, 1914-1924 25-85 (1993). 
issues. $^{129}$

\section{A. Default}

Already by 1929 the dioceses most involved began discussions with Dutch creditors to reduce the relatively high interest rates to a level more consonant with the market conditions of the immediate pre-depression period. ${ }^{130}$ Any number of institutions issuing these instruments could be used to illustrate the latter's post-issuance fate; for convenience, a case study based on the principal parish church (the Münster) of Bonn will serve pars pro toto.

From the time of the Kulturkampf of the Bismarck Era on, ${ }^{131}$ German administrative law had required Catholic church institutions proposing to issue bonds to obtain the approval of the relevant state authorities and not only of the relevant church authorities. ${ }^{132}$ In fact, the first issue proposed by the Bonn parish and carrying the typically generous interest rate deemed necessary to encourage their placement was prohibited by the Cologne archdiocese on the ground that the rate was too high even in that context. And when finally approved in 1928 by both the secular and the church

129. See Josef van Elten, Die Holland-Anleihen des Bistums Hildesheim, Die Diözese Hildesheim in Vergangenheit und Gegenwart, 57 JAHRBUCH D. VEREINS F. GESCHICHTE U. KUNST IM BISTUM HILDESHEIM 101 (1989), who points to the number of Catholic orphanages, hospitals, and schools that had little in the way of assets to begin with and thus found this source of funding especially important. In fact, according to GLASEMANN, supra note 10, at 124 , the first two of almost 300 Catholic Hfl (Dutch gulden) loans, dated January 1, 1925, were issued by a local hospital and a local charitable society respectively. An Occupation-era listing of January 24, 1942, arrayed by location of issuing body and listing 229 issues, was provided by a Dutch bank, Rebholz' Bankierskantoor, Amsterdam, as part of a solicitation of these debtors to help them pay off these debts during the Occupation (listing on file with author).

130. See Cologne Diocesan Archive, Folder 1073.

131. Section 50 of the Gesetz über die Vermögensverwaltung in den katholischen Kirchengemeinden [Law Concerning the Administration of the Assets of the Catholic Parishes] of June 20, 1875 required loans and bond issues proposed by the church authorities to obtain the approval of the Prussian state authorities. Later ministerial decrees extended this requirement specifically to include all conditions of the loans as well as the terms of payment. See the primary texts and editorial commentary in G. KÜHLING, DIE VERWALTUNG DES KIRCHENVERMÖGENS 29 and more generally 11 and note 1 (3d ed., 1908), a reference kindly provided me by Dr. van Elten. Modern treatments of the legal history include ADALBERT ERLER, KirCHENRECHT 58 (5th ed., 1983); see also the cultural-political treatment by MARTIN HECKEL, VOM RELIGIONSKONFLIKT ZUR AUSGLEICHSORDNUNG (2007).

132. The statute applicable by this time was the Gesetz über die Verwaltung des katholischen Kirchenvermögens of July 24, 1924, Nordrhein-Westfalen, GS S. 585/SGV NRW 222 (repealed after WW II). Paragraph 15 required state authorization for bond issues. To this remnant of state control (now justified principally because of its relation to the Kirchensteuer-the state-collected tax imposed on members of established religious denominations and paid to these) see the extensive and critical analysis of HANS CARL NiPPERDEY, II DIE GRUNDRECHTE UND GRUNDPFLICHTEN DER REICHSVERFASSUNG 412 (1930). 
authorities, many of these issues were beginning to run into servicing difficulties. Already by 1929 the German dioceses most involved had begun discussions with Dutch creditors to reduce the relatively high interest rates (typically $8 \%$ or $7 \%$ ) to a level more consonant with the market conditions of the immediate pre-depression period.

By the time of the last (Brüning) government of the Weimar era and of the first year of the Third Reich stronger measures were deemed necessary and various currency restrictions were being put in place constraining all Reich, state, local public- and private-sector and Catholic bond servicing obligations. ${ }^{133}$ The larger story - the increasingly coercive use of the Konversionskasse and of the Standstill arrangements-already has been described above. Some of those practices also applied to the two Dutch cases, but here a first diversion from the general narrative is needed. Two unique elements now appeared. The first is specific to the Catholic bond issues; the second applies to them as well as to state bonds.

Some church authorities, in particular the Cologne archdiocese, represented by a sophisticated and strategic counsellor, ${ }^{134}$ vigorously resisted the Konversionskasse approach, and this on two grounds. Cologne's close ties to the Dutch church and consequent negotiation position was considered superior to that available to the Berlin authorities. Cologne also was thought to be in a better position to obtain permission to continue using increasingly scarce foreign currency reserves to honor the interest obligations ${ }^{135}$ (even as it participated in the general effort to get creditors' agreement to lower interest rates and extend maturities).

133. Culminating in the Devisengesetz [Payment Instruments Law], Dec. 12, 1938, RGBL. I at 1733. The law confirmed interim regulations that required all payments to and claims against foreign parties by German subjects, including specifically bond issues in foreign denominations, to be transacted through the Reichsbank; and continued a 1937 provision that mandated the reduction of the contractual interest rate to four percent on any obligation a foreign holder chose not to settle by receipt of Reichsmark (see CHILD, supra note 18, at 101-32).

Enacted after the Reichskristallnacht pogrom of November 1938, the statute also included the notorious $\S 58$, permitting emigrating Jews to take only necessary personal items and no foreign currency. A personal recollection: once on board ship to the U.S., each adult passenger was allowed to exchange RM 10 for approximately $\$ 2.50$ daily; an eight-day journey thus allowed a passenger to arrive with $\$ 20$.

134. Carl Lohmanns, who served the Archdiocese as external counsel for decades, from the interwar through the war and well into the postwar periods. See his characterization in van Elten, supra note 130 , at 111 .

135. An increasingly dangerous path, as the Third Reich criminalized all efforts to circumvent its ever stricter convertible-currency prohibitions. See Maria Zumholz, Verbrecher oder Märtyrer? [Criminals or Martyrs?], in CHRISTENKREUZ ODER HAKENREUZ (Willi Baumann \& Michael Hirschfeld, eds., Vechta 1999); and more generally, contextualizing these prosecutions within the larger anti-Catholic campaign that began in 1935, ERNST HOFFMANN \& HUBERT JANSSEN, DiE WAHRHEIT ÜBER DIE ORDENSDEVISENPROZESSE (1967), as cited in van Elten, supra note 130, at 109. 
This led to an intra-church dispute. Other archdioceses, organized by the all-German Fulda Bishops' Conference, had thrown in their lot with a centralized state-led effort to handle these negotiations, a nominally privatesector office created in 1937 that was under the control of the Konversionskasse. ${ }^{136}$ Lohmanns, the Cologne Archdiocese's counsel, objected to this approach, claiming that Cologne's close connection to the Dutch church authorities would lead to better results in the inevitable negotiations to reduce the interest-rate burden. ${ }^{137}$ The Cologne Archdiocese in fact did avoid being placed under this umbrella and was able to negotiate interest-rate reductions for its 1927 bond issues with the Dutch bondholder representative at least as favorable as those Berlin achieved.

All of these efforts, however, were only the prelude to the fate of these (and many other) bonds and their Dutch holders during the wartime occupation of the Netherlands. The Dutch economy had been to a greater or lesser degree dependent on the German economy from the time of Dutch independence on, in part because of its geographical position at the mouth of the Rhine and thus at the door to Germany's principal sea trade routes. ${ }^{138}$ Already during the Bismarck Era and especially during World War I the country had come close to political dependence as well; and with the economic autarchy practiced by the Third Reich, the trade imbalance of payments had led to ever greater problems already before World War II. ${ }^{139}$

136. The Zentralstelle zur Betreuung ausländischer Anleihen katholischer kirchlicher und caritativer Einrichtungen [Central Office for the Support of the Foreign Loans of Catholic Church and Charitable Organizations], in Berlin, where the office of the Konversionskasse was located. See Bischöfliches Archiv Köln (BAK), Cologne Diocesan Archive, Folder CR II 14.1a.1 (1936-1953). The Konversionskasse itself was a creature of the Reichsbank; see Satzung der Konversionskasse [Charter of the KK], July 3, 1933, RAnz of same date.

137. When the Zentralstelle sent a questionnaire intended to establish an accurate list of all such obligations to the relevant addressees, Lohmanns apparently wrote to the principal dioceses suggesting that this was an illegitimate monopolization of more decentralized and direct negotiations of borrowers with lenders, leading to a stiff note from an official of that office calling his intervention unfounded [unsachlich]. Id.

138. For a brief overview of this situation and its political as well as economic ramifications, see Hein Klemann \& Friso Wielenga, Die Niederlande und Deutschland, oder verschwindet die nationale Ökonomie? Eine Einleitung [The Netherlands and Germany, or is the National Economy Disappearing? An Introduction], in DeUTSCHLAND UND DIE NIEDERLANDE 7, 12 (Hein Klemann \& Friso Wielenga eds., 2009).

139. The Netherlands was the principal though not only country with which already the last Weimar (Brüning) government negotiated bilateral clearing arrangements intended to keep the German trade-related balance-of-payments deficits in check; agreements the Third Reich regime significantly extended in the context of the Konversionskasse program. In lieu of primary citations, see Hein Klemann, Wirtschaftliche Verflechtung im Schatten zweier Kriege [Economic Networks in the Shadow of Two Wars], in KLEMANN \& WIELENGA, supra note 142, at 19, 38.

For the postwar debate among political economists concerning the motives of the Third Reich driving these trade policies, and the now dominant argument that it "sacrificed terms of trade for political advantage," reversing that strategy only after the occupation of the affected countries, see 
Now, early in the Occupation, the equivalent of a currency union also was imposed. ${ }^{140}$ Among its many consequences, one is particularly relevant to this account; namely, the payment at maturity (when applicable) and the early redemption (when not) of gulden-denominated bonds at a false exchange rate. ${ }^{141}$ Basically, the elimination of the convertible-currency constraints cleared the way to more or less coerced delivery by Dutch holders of these bonds in exchange for other instruments or for payment at these false exchange rates. ${ }^{142}$ This was the false conversion [unechte Konversion] problem, as it was labeled by the negotiators of the London Debt Agreement ("LDA") after the war. The LDA, in consequence, more or less invited German authorities, if presented with Dutch governmental and individual arguments that these payments did not extinguish the underlying debts, to reopen the question of payment.

Albrecht Ritschl, Nazi Economic Imperialism and the Exploitation of the Small: Evidence from Germany's Secret Foreign Exchange Balances, 1938-1940, 54 ECON. HIST. REV. 324 (2001).

140. Aufhebung der Devisenbeschränkungen gegenüber den besetzten niederländischen Gebieten [Repeal of the Currency Restrictions in the Occupied Dutch Territories], RWM-Erlaß, Mar. 31, 1941, Vol. 31, Reichsteuerblatt No. 279, April 3, 1942, 255f. Formally, the Dutch gulden remained in circulation; the effect of the decree was to remove the earlier exchange restrictions and substitute free convertibility at the pegged exchange rate of $1 \mathrm{hfl}=\mathrm{RM} 1.327$, which both disadvantaged Dutch parties — see Jaap Baerendregt, The Dutch Money Purge 22 (Diss., Amsterdam 1993) - and led to a serious risk of inflation spilling over into the wartime German economy. A major intra-ministerial dispute erupted within the Reich Cabinet, leading to Foreign Office officials and military occupation authorities reprimanding the Finance Ministry and "super-Minister" Göring over their dismissal of these concerns. See, e.g., Reichsminister Schwerin von Krosigk to Reichsmarschall Göring, Sep. 12, 1942, PA AA R 105308 (Handakten Riegner).

141. The mechanism needs explaining. Article I(4) of the mentioned Regulation freed the issuers of both state and religious debt instruments from the general prohibition of the use of foreign exchange and allowed payments but at the artificial pegged rate. This led both private and Occupation-ordered pressure on Dutch holders of both types of instruments to allow early redemption or, even better, to sell their holdings on informal secondary markets at seriously discounted prices. The Regulation is perfectly clear on this; indeed, its Annex 2 lists, for example, all twenty four German prewar private-sector bond issues individually as available for these transactions and - most significantly — adds a blanket inclusion of "all loans of domestic [German] religious communities, cloisters, charitable institutions, schools, etc." in this authorization. In the absence of archival evidence one can only speculate on the channels that led the Third-Reich government, by then already markedly hostile to the Catholic Church, to this step.

142. The advantage to the German religious bodies of this opportunity was quickly recognized and energetically exploited. For example, a German church overseer of a Dutch old-age home requested a loan from the Occupation Authorities to be used for the repurchase and cancellation of the bonds it had earlier issued in Cologne. See Cologne Diocesan Archive, Folder 1073. After the war, when bondholders had to pass through the validation filters, Lohmanns pointed out that the process was of no concern to the Cologne Diocese as all bonds issued by it had been repurchased or redeemed during the occupation. See Letter from Lohmanns, to the Deutscher Verein vom Heiligen Lande [German Society for the Holy Land] (Apr. 17, 1952) (on file with the BONN MÜNSTER ARCHIVE, Folder 192); Letter from Lohmanns, to the Deutscher Verein vom Heiligen Lande (June 25,1952 ) (on file with the BONN MÜNSTER ARCHIVE, Folder 192). Indeed, he there pointed out that during the Occupation he had advised his church clients not to redeem (at par) but to buy up their bonds at the far more discounted (and still pegged) secondary-market rates. Id. 
This was, however, an illusory invitation so far as Catholic Church debt instruments were concerned. LDA Annex IV, setting forth "Agreed Recommendations" for the settlement of a miscellany of prewar transactions, indeed applied to a number of situations in which, as previously discussed, German debtors paid their foreign-denominated debts in Reichsmark to the Konversionskasse, leading to these postwar arguments of inadequate payment. Article 23 of this Annex specifically recognized that Occupation-Era settlements were presumed to be "unecht" if effected by German authorities without the creditor's consent.

Article 23(5), however, excluded holders of the Church bonds from this benefit by the simple expedient of declaring that any conversion in the case of Church loans "shall be considered effective." This segregation of the religious-organization goats from the secular-organization sheep had its own consequences for the postwar compensation battles stubbornly fought by the Dutch government on behalf of both groups, ${ }^{143}$ battles to which the following section is devoted.

This led to considerable debate in the quasi-official committee later set up by the German government (and chaired by Abs) to consider all issues concerning the application of Article 23 to contested claims arising out of state and private-sector redemptions, and specifically focused on the Dutch case. After initial efforts to repel these claims, largely on the ground that the Dutch government had not signed the LDA, the committee accepted as a default proposition in all but the church cases that these redemptions and cancellations indeed were "unecht" and required further payment.

\section{B. Dutch Claims in the Post-LDA Period}

The Dutch negotiators, joined by the Norwegian team, worked hard but in vain to exclude all of their war and occupation-related reparations claims from the moratorium deferring their presentation that was promulgated by LDA article $5 .{ }^{144}$ This effort was rejected by the principal Allied

143. The Dutch, joined by the Norwegian government, fought in vain to avoid the bar of the Article 5(2) moratorium on all reparations claims, to the point that the former refused to sign and ratify the LDA for several years.

144. See Richard M. BuXbaum, The London Debt Agreement of 1953 and Its Consequences, in BALANCING OF INTERESTS - LIBER AMICORUM PETER HAY 55, 55-72 (H-E. Rasmussen-Bonne et al. eds., 2005) (detailing the Dutch position). While primarily focused on "wage" claims of Dutch forced laborers, it also and specifically argued for restitution of gulden-as well as RMdenominated bonds, which had been paid off at false exchange rates. See also URSULA ROMBECKJASCHINSKI, Schuld gegen Schulden? Die niederländischen Entschädigungsansprüche an die Bundesrepublik Deutschland 1950-1960, in ANKNÜPFUNGEN - GEDENKSCHRIFT PETER HÜTTENBERGER 347, 413 (Volker Ackermann et al., eds., 1995) ("bonds seized from their Dutch holders"). The Dutch government, as mentioned, did in fact refuse its consent to the LDA for some 
negotiators, basically on the argument that prewar private claims and postwar Allied occupation-cost claims would not be satisfied if occupationrelated reparation claims also were to be part of the agenda. In a later speech Abs, who knew the Dutch situation well, asserted that the bond claims (and related reparations claims) amounted to RM seven billion; he expressed considerable satisfaction that this effort had been repelled. ${ }^{145}$

The Dutch fought back in kind, in particular by seizing German public and private assets over which they had control, and in some cases obtaining the cooperation of other Allies to gain possession of assets in their states. In this, the Dutch activities were not unique, even if the wartime Occupation Era did distinguish their situation and postwar reaction from similar actions taken by the major Allies, particularly the United States and the United Kingdom. ${ }^{146}$ These setoff issues, as previously mentioned, were a major bone of contention between the major Allies and the Netherlands, to the point of leading to the Dutch rejection of the LDA arrangement for several years. However, they were resolved over time, and were essentially taken off the table with the acceptance of the multi-faceted bilateral reparation agreement. $^{147}$

One episode, however, stands out because of its specific association with the Church Bonds story, and deserves brief description. ${ }^{148}$

A major recurrent source of income of the German Society for the Holy Land (Deutscher Verein vom Heiligen Lande) was the receipt of the

years. It came on board later, when the set of German bilateral Reparation Agreements with Allied and some Neutral States came on the agenda beginning in the late 1950s.

145. Hermann J. Abs, Das Londoner Schuldenabkommen, in AUS VORTRÄGEN VON HERMANN J. ABS 12 (1953).

146. The story of both WW I and WW II "freezing and vesting" of privately owned property of enemy subjects has been the subject of much discussion; for an overview of this literature, with further citations, see RICHARD M. BUXBAUM, Equalization of Burdens, in II FESTSCHRIFT FÜR ERIK JAYME 1051 (H.-P. Mansel et al., eds., 2004). Specific to the second postwar situation were the efforts to negotiate-some argued to coerce - the turnover of such assets located in neutral countries, in particular in Portugal, Sweden and Switzerland. The two Swiss-American Washington Accords offer the paradigmatic example. See LinUS VON CASTELMUR, SCHWEIZERISCH-ALLIIERTE FINANZBEZIEHUNGEN IM ÜBERGANG VOM ZWEITEN WELTKRIEG ZUM KALTEN KRIEG [SWISSAllied Financial Relations in the Transition from World War II to the COLD WaR] (1992) (providing a full review).

147. The German-Dutch Agreement did include these forced-labor claims as well as nonrecourse for the Dutch confiscations of German properties (discussed immediately below). Financial Treaty, Ger.-Neth., Apr. 8, 1960, 509 U.N.T.S. 194. It settled the issue of "false conversions" with a substantial German payment but without German acceptance of the Dutch characterization thereof. See ROMBECK-JASCHINSKI, supra note 145. For a full discussion of the negotiations and of these results, in particular how the victim-compensation (reparations) issues were quietly inserted in the Finance Agreement portion of the overall multi-component treaty, see also FÉAUX DE LA CROIX, Staatsvertragliche Ergänzungen der Entschädigung, in DER WERDEGANG DES ENTSCHÄDIGUNGSRECHTS $231 \mathrm{ff}$ (Fed. Min. Finance \& Walter Schwarz, eds., 1985).

148. This factual overview is contained in the Cologne Diocesan Archive, Folder 192. 
Pontifical Good Friday Collection, the annual collection in all Catholic churches transferred directly to the Holy See for missionary and related purposes. $^{149}$ A second source came from its own bond issue of 1930, denominated in Dutch gulden and placed with the cooperation (and to an uncertain degree with a guarantee) of the Cologne Archdiocese through Cologne's Dutch channels. During World War II the Society's activities in Palestine were on hold, and it invested much of its Pontifical Good Friday Collection income (held for the time being in Germany) in the type of redemption of its Dutch issue that later led, in other cases, to the "forced conversion" arguments.

After the war the usual debate over these problems, already familiar in the larger context of all German state and local Dutch-denominated bond issues, erupted - with one twist. Already in the late Palestine Mandate era and continuing after foundation of the state of Israel, Dutch authorities succeeded in obtaining possession of the properties of the Society located there. ${ }^{150}$

Following the rejection of Dutch reparations claims by the LDA arrangement, ${ }^{151}$ its government, through its Commission for the Legal Correction of Foreign Instruments (Commissie Rechtsherstel Buitenlandse Effecten) offered only a small percentage of the value of these confiscations to German claimants on the argument that this was the equivalent of the recovery on its claims. In the specific case of the German Society for the Holy Land this led to a vigorously prosecuted but eventually fruitless effort to enlist the good offices of the Holy See directly in negotiations with the Dutch. In the end Lohmanns advised the Palestine Society representative that it would be wiser to have Cologne's Cardinal Frings, highly respected by the Dutch government (specifically by the Catholic Foreign Minister, Luns), take on this effort.

As already pointed out, however, this episode too was indirectly resolved in the later bilateral agreement with the Federal Republic of Germany. Efforts to discover whether and to what extent some of the funds received by the Dutch government for both compensation and creditorrepayment purposes actually came to the holders of the church bonds have

149. For a description of the many Catholic church annual collections, including the Pontifical Good Friday Collection, see National Collections Schedule For 2016/2017, http://www.usccb.org/about/national-collections/upload/2016-2017-Collection-Schedule.pdf (last visited Oct. 10, 2016, 7:10 PM).

150. Even though the State of Israel itself refrained from any seizure of religious-organization properties. Id.

151. And recall that the LDA exempted church issuers from the obligation to make good on any forced-conversion claims. See supra notes $147-48$ and accompanying text. 
foundered on Dutch privacy and data-protection barriers. ${ }^{152}$

\section{CONCLUDING REFLECTIONS}

This story well illustrates the competing if not conflicting pulls and tugs of fidelity to doctrine and fidelity to admittedly vague concepts of justice. Perhaps the single aspect most salient to an appropriate resolution of these disputes is the one not articulated in any of the reviewed decisions: Can claimants today still demonstrate or at least claim the benefit of the doubt concerning their appeal to justice, including to good faith? Putting aside the always looming question of validation of title, it is probable that most claimants are not original debt holders or their familial successors (including corporate successors to original corporate holders), but secondary purchasers or assignees. Is there a point over these almost epochal time periods when these claims fairly may be considered extinguished, quite apart from prescription rules?

It is not an easy question. Secondary markets have a role to play and the "vulture" label does not per se trivialize that role. ${ }^{153}$ Consider also this fact (familiar from the domestic bankruptcy context): The original Cuban Claims bill contained a section providing that the amount determined to be due in any certification of a presented claim could not exceed the amount of consideration paid for the claim, a proviso clearly aimed at assigned or otherwise acquired claims transferred by the originally expropriated property holder. ${ }^{154}$ That limitation did not survive to become part of the enacted statute, and its evaporation is significant. Consider also, however, the condition of the already mentioned and increasingly suspect secondary postwar markets in which these German bonds were variously available, let alone the dubious non-market channels along which these instruments traveled both in the first two postwar decades and then again in the later GDR and early post-unification periods. ${ }^{155}$ The mutation of these venues from those resembling a curb market to those functioning as an "antiques

152. To the foregoing, see Lohmanns, Aide Memoire to Vatican (on file with the Cologne Diocesan Archive, Folder 192 (Dec. 18, 1962) (recounting this decade-long set of discussions and negotiations).

153. Consider only the many current cases involving the Argentine and now the Greek defaults.

154. See H.R. REP. No. 12-259, at 5 (1964) (quoting § 507(b) of the draft legislation).

155. Two references buttress this comment. In addition to the previously mentioned "markets," earlier private channels are vividly described in an account by a participant convicted for his role in their use. See Scott Stockdale, History's Greatest Fraud (2002). And an investigative journalistic report of the machinations leading to the offer of these types of bonds from the vaults of the GDR suggests a good deal of fraudulent if not even criminal activity in the opening of these channels: ANDREAS FÖRSTER, SCHATZRÄUBER (2000). 
and collectibles" store if not as a fences' market suggests the diminishing reasonableness of any effort to convert the revival of such dead instruments into a basis for legitimate claims. ${ }^{156}$

That is not to say the late presentation of bonds by successors, in traditional heirship contexts, would be precluded. ${ }^{157}$ That is, indeed, the situation that existed after unification, and as already mentioned it was resolved through administrative processes not necessarily under the earlier Federal Republic validation legislation, ${ }^{158}$ but by analogy thereto, an analogous process that included the application of typical Civil-Code prescription periods. The reports of the federal agency responsible for the review of these applications indicate that a substantial number of claims based on "East German" bond issues of the Weimar Era were received and upon adequate proof of ownership paid. ${ }^{159}$ Whether this set of claims included claims by successors to instruments with proof of a good chain of title is not clear from these reports. That should not matter, so long as the original claimant's title could pass muster in the terms of the earlier validation processes. ${ }^{160}$

The question of limitations periods and their tolling becomes ever more

156. It is only a thin analogy, but the classic distinction in U.S. criminal law between the legitimacy of enacting an extension of a statute of limitations at a time when the affected persons still are under threat of prosecution under the existing one, and extending it when the affected persons have "come to rest" due to the running of the earlier prescription period comes to mind. See Grunewald v. United States, 353 U.S. 391, 396-98 (1957). By the arrival of the new century, these bonds had come to their final resting place.

157. In this non-market sense, the difference between financial and non-financial assets is irrelevant. Thus, under the German statute guiding the role of the Property Commission created in the context of the Foundation for Remembrance, Responsibility and the Future, both types of assets, seized by German occupation authorities in the occupied countries, were eligible for compensation if the claims came from the usual chain of heirship. See Section 13, Gesetz zur Errichtung Einer Stiftung "Erinnerung, Verantwortung und Zukunft" [Law on the Creation of a Foundation "Remembrance, Responsibility and Future"], Aug. 2, 2000, BGBL. I at 1263.

158. The issue is a complicated one. The old validations laws continued to be operative for debt instruments issued by Weimar-era borrowers for whose debts the original Federal Republic had accepted responsibility, but not for issues of lower-level "East German" borrowers (other than Prussia). For those, presentation was a possibility under ordinary Civil-Law provisions and in some instances under special statutes such as the Equalization of Burdens and the War Consequences statutes of the earlier postwar era. Even then the two additional major filters; namely, prescription and succession, as already described, seem to have been applicable.

159. See BADV, supra note 71. Direct evidence hereof, however, in the form of actual court decisions, is not available.

160. As a clearly knowledgeable blogger put it in 2001, when the federal government began organizing this new process, proofs could include, in addition to the instruments themselves, public documents, proof of partial liquidation, bank certificates [of earlier holdings], excerpts from deposit confirmations, accounts of transactions or similar items. Avator, FILHDONOS (June 4, 2001) Contribution No. 3 ("Als Beweisunterlagen können neben den Anleihetiteln auch öffentliche Urkunden, Teilliquidationsnachweise und Bankbescheinigungen, Depotauszüge, Effektenabrechnungen oder ähnliches vorgelegt werden”). 
significant in this larger policy sense. Two cases rejecting old claims, though through different analyses, illustrate this general problem. In Jackson v. People's Republic of China ${ }^{161}$ a suit brought in the late 1980s, the bonds in question were issued by the Imperial Government in $1911^{162}$ and the opinion describes disputes concerning their renegotiation both in the 1930s and again after World War II, disputes the court did not have to resolve given its dispositive ruling but disputes typical of this kind of litigation. ${ }^{163}$ In Carl Marks \& Co., Inc. v. Union of Soviet Socialist Republics,${ }^{164}$ plaintiff, a prominent dealer in these types of securities, brought suit in the 1980s on bonds issued by the Imperial Government in 1916 that by their terms had matured in 1921. Again, given the dispositive ruling, no conclusion concerning staleness was reached, though a literary quotation with which the District Court began its opinion is worth recalling. ${ }^{165}$ Since the Supreme Court's acceptance of the retroactive effect of the FSIA in Altmann, ${ }^{166}$ however, at least indirectly challenging the basis

161. 794 F.2d 1490 (11th Cir. 1986), cert. denied, 480 U.S. 917 (1987).

162. The Hukuang Railway Bonds, argued by some to have been the trigger of the revolution that overthrew the imperial regime. See EIKo Woodhouse, The Chinese HSinhai Revolution: G.E. MORRISON AND ANGLO-JAPANESE RELATIONS, 1897-1920 42 (2004).

163. In reviewing the issues, the court stated:

Plaintiffs introduced expert testimony in the district court attempting to show that the bonds were renegotiated in 1937 by an agreement between the Chinese Nationalist government and an American bondholders' committee representing the lenders, providing for an interim interest rate reduction and for amortization to begin again in 1949 and to be completed in 39 years from 1937, which would be 1976. Statements filed by the PRC say that renegotiation was discussed but no agreement reached. Plaintiffs say that the obligations under the bonds were "reaffirmed" by the Nationalist government just before its departure for Taiwan in 1948. The district court found that the renegotiation was never agreed upon, and that the bonds matured in 1951, the original maturity date.

Jackson, 794 F.2d at 1491-92 (internal citations omitted).

164. 841 F.2d 26 (2d Cir. 1988), cert. denied, 487 U.S. 1219 (1988).

165. - Yes well there was just one more thing here I, that I think you might ...

- That? My God, haven't seen one in years.

-No this isn't what I ... what is it.

-Russian Imperial Bond.

- You mean it isn't worth any, worth very ...

- Mister Bast, anything is worth whatever some damn fool will pay for it, only reason somebody can make a market in Russian Imperials is because some damn, somebody like your associate will buy them. Happen to know how he, how this associate of yours got into all this?

- By, well, buying and selling at first I think and then he had some stock in a company and was going to bring some kind of legal suit for, for his class, I mean he ...

-A class action?

665 F. Supp. 323, 324 (S.D.N.Y. July 31, 1987) (quoting WiLliam GADDIS, JR 201 (1975)). The Carl Marks case was, in fact, brought as a class action.

166. Republic of Austria v. Altmann, 541 U.S. 677, 697-700 (2004). 
on which both cases had been dismissed, the prescription question would come to the fore; indeed, as the earlier-reviewed World Holdings ruling demonstrates, has come to the fore. ${ }^{167}$ And in the German unification context this kind of disposition (and its German judicial kin) is essentially a technical doctrinal mask for a deeper and understandable sense of ill ease about the disturbance of a long-sought repose.

This is not to say that political resolutions of these decades-old disputes do not occur. ${ }^{168}$ Thus, in 1986 the United Kingdom and the Soviet Union agreed to settle property claims - in the case of the United Kingdom, on behalf of itself and its subjects - that included Czarist-era government debt repudiated by the new Soviet government. ${ }^{169}$ And following agitation by bondholders' associations specializing in Czarist bonds (presumably held by the descendants of the many White Russians who fled the Bolshevik Revolution for French refuge), an even more elaborate Franco-Russian treaty was signed a decade later. ${ }^{170}$ Rejectionists immediately brought suit against the French state for limiting their claims to the fund established by the accord, but were unsuccessful. ${ }^{171}$ On the other hand, possible efforts by

167. But so would, and have, concerns about the outer limits of any reasonable application of norms analogous to the doctrine of equitable tolling. A good recent example of their review by the US Supreme Court is found in Credit Suisse Secs. (USA) LLC v. Simmonds, 132 S. Ct. 1414, 1421 (2012).

168. In this connection, the theoretical debates over reasons of state compliance with norms of customary or conventional international law are illuminating, even if for the narrow purposes of this narrative I do not engage them.

169. Agreement concerning the Settlement of Mutual Financial and Property Claims arising before 1939, U.K.-Soviet Union, July 15, 1986, Treaty Series No. 65.

170. Labelled a Memorandum d'Accord, it was legislated expressis verbis. Agreement Between the Government of the French Republic and the Government of the Russian Federation on the Final Settlement of Mutual Claims Between France and Russia Prior to May 9, 1945, Fr-Rus., May 6, 1998, Journal OfFICIEL DE LA RÉPUBLIQUe FranÇAiSE [J.O.] [Official Gazette of France], May $15,1998,7378$. It provided for the payment of $\$ 400,000,000$ (specifically in US dollars), a sum disparaged as derisory by rejectionist French bondholders who immediately commenced litigation against the state.

171. See, e.g., Conseil d'Etat [CE] [highest administrative court: sits in sub-section (CE), section (CE Sect.), or assembly (CE Ass.)] Feb. 21, 2003, No. 226489.

While it is not my aim to replow the 11th Amendment story from Chisholm v. Georgia to or beyond Hans $v$. Louisiana, this is an appropriate place to note the long domestic sequel to the antebellum years of the 19th Century in this bond-issue context. For an abundance of both technical and political-economic work, see, e.g., the compilations and analyses of John Joseph Wallis, Richard E. Sylla, \& Arthur Grinath III, Sovereign Debt and Repudiation: The Emerging-Market Debt Crisis in the U.S. States, 1839-1843, NBER WORKING PAPER 10753, (2004), http://www.nber.org/papers/w10753.pdf; William B. English, Understanding the Costs of Sovereign Default: American State Debts in the 1840's, 86 AM. ECON. R. 259 (1996).

The oldest post-Chisholm state bond issues to be the subject of litigation in the U.S. courts were those of the Planters' Bank Bonds issued by the State of Mississippi in 1831-33. A full century later the U.S. Supreme Court denied standing on 11th Amendment grounds to a foreign sovereign suing on these bonds. See Principality of Monaco v. Mississippi, 292 U.S. 313, 332 (1934). However, a U.S. state's suit on similar antebellum bonds also donated by a private party 
these claimants to sue the foreign state directly would be another matter. In some regimes, the waiver typical of such arrangements (i.e., "waive on behalf of its nationals") would not necessarily bar direct actions by the individual claimants. ${ }^{172}$ Thus, in an analogous context, the legislation establishing the Foreign Claims Settlement Commission certification and payments process typically and expressly stated that it did not preclude other collection efforts to obtain payment of any unpaid balance. ${ }^{173}$

Finally, the gold-clause era and its treatment in the numerous decisions collected by Nussbaum and selectively reviewed earlier suggest another, deeper policy response. A point arrives at which the raison d'etat,

was of course not subject to this bar. See South Dakota v. North Carolina, 192 U.S. 286, 321-22 (1904) and the wider context provided in JOHN V. ORTH, THE JUdicial POWER OF THE UNITED StATES: The ElEVENTH AMENDMENT IN AMERICAN History 141 (1987). As recently as the 1980s a British Bondholders Council still was trying for a political settlement in relation to these bonds, most of which had been placed there. See One Hundred and Fifteenth Annual Report of the Council of the Corporation of Foreign Bondholders, http://sulderivatives.stanford.edu/derivative?CSNID $=00003103 \&$ mediaType $=$ application $/$ pdf (last visited Sept. 24, 2016) (deciding to end the effort). A last (for now) effort in a U.S. state court failed a decade later. See Lilley v. Missouri, 920 F. Supp. 1035, 1045 (E.D. Mo. Feb. 27, 1996).

In absolute terms, the winner seems to be a Dutch bond of 1648. See the story of Yale University's windfall at David De Jong, Yale to be Paid Interest on Dutch Water Authority Bond from 1648, BLOOMBERG (Sept. 16, 2015, 6:28 AM), http://www.bloomberg.com/news/articles/201509-16/yale-to-be-paid-interest-on-dutch-water-authority-bond-from-1648.

172. While I put aside here the problem of the jurisdictional immunity of the foreign sovereign, it is interesting that the German Federal Constitutional Court, in the highly politicized context of claims against the Federal Republic by former slave and forced laborers who were subjects of states that had by treaty provided these waivers, ruled that the state waiver did not necessarily preclude direct private actions. Compare Bundesverfassungsgericht [BVERFG] [Federal Constitutional Court], May 13, 1996, 94 ENTSCHEIDUNGEN DES BunDESVERFASSUNGSGERICHTS [BVERFGE] 315, 331 (finding that no norm of customary international law precludes victim's direct action, while reserving the question of a treaty's possible effect thereon, depending on its specific phrasing) with Deutsch v. Turner Corp., 324 F.3d 692, 716 (9th Cir. 2003), cert. denied sub nom. Suk Yoon Kim v. Ishikawajima Harima Heavy Indus., Ltd., 540 U.S. 820 (2003) (finding the USJapan treaty waiver provision a bar to private actions, even by subjects of a nation (Korea) that was not a party thereto).

173. In lieu of detailed citations, see the most recent use of this authorization in De Csepel v. Republic of Hungary, 808 F. Supp. 2d 113, 134-35 (D.D.C. 2011), aff'd in part \& rev'd in part, 714 F.3d 591 (D.C. Cir. 2013). More generally, this also is true of the older versions of interstate agreements setting off the expropriated assets of one nation's subjects against the frozen assets of the expropriating state and its subjects, going back to the Litvinov Assignment of 1933 and to classic postwar agreements such as the Anglo-Soviet Agreement of 1968. See United States v. Pink, 315 U.S. 203, 234 (1942); see also Richard B. Lillich, The Anglo-Soviet Claims Agreement of 1968, 21 INT'L \& COMP. L.Q. 1, 5-13 (1972). Some claims on pre-Soviet era bonds, if reduced to judgment by 1933, were paid (on a proportional basis) from the United States proceeds under the Assignment. International Claims Settlement Act of 1949 § 305(a), 22 U.S.C. § 1641d (2012). See, e.g., Erskine Rogers Claim, USFCSC Decision of February 27, 1957, FCSC, 10th Report (1957) 180, as reported in 26 INT'L L. REP. 257 (1958) (apparently allowing compensation even in the absence of a prior judgment). Again, the availability of this route to partial satisfaction did not automatically bar (unsuccessful) efforts to collect the balance through later litigation, as the facts of the Carl Marks case suggest. Carl Marks \& Co., Inc. v. Union of Soviet Socialist Republics, 665 F. Supp. 323, 326-28 (S.D.N.Y. July 31, 1987). 
understandably discredited in reaction to its 19th Century abuse, arises in more modest garb when a state's unavoidable concern with how to dispense and ration justice for past wrongs reaches its limits. The political power of private claimants, and the politically driven considerations of the respondent state how to resolve past disturbed relationships with these claimants and their various state champions, may trump more fine-grained arguments of complete justice. ${ }^{174}$ What begins as state-supported creditor-organized blocs battling a tainted and weakened state - the LDA context is the perfect example - ends with politically feeble and perhaps politically disrespected ragtag bands hoping to hook the brass ring of equal justice through pseudoLockean justifications of market dignity. The catalogue of postwar German legislation bears witness to this struggle, of which the post-unification stage is only the last, less and less sensitive manifestation: Restitution laws, Compensation laws, Equalization of Burden laws, Consequences of War laws, Hardship laws, Financial Asset Validation laws, bilateral reparations treaties, Open Property-Questions laws - the list goes on and the moral energy to listen goes down. ${ }^{175}$

Given the eligibility criteria for pension payments to surviving spouses of pre-Third Reich civil servants who were expelled from their positions on grounds of religious or political persecution, the continuation of these obligations until approximately the year 2037 is plausible. ${ }^{176}$ Hobsbawm's "twilight zone" 177 between the lived experience and the cold record of history still has not ended but its landmarks are less and less discernible.

174. See generally Stuart Eizenstat, ImPerfect Justice: Looted Assets, Slave Labor, AND THE UNFINISHED BUSINESS OF WORLD WAR II (2003).

175. For a fine-grained moral-philosophical treatment of this difficult point, see NAHSHON PereZ, Freedom from PAST InJUSTICES: A CRitical EVAluation OF Claims fOR INTERGENERATIONAL REPARATIONS 100-19 (2012).

176. Since the basic compensation statutes make such a spouse or dependent eligible for pensions if born as late as early 1945 (i.e., now 70 years of age), that date is actuarially speaking reasonable - and would incidentally mark the century mark of the pre-expansion borders of the Third Reich, a date relevant for determination of eligibility for compensation and restitution under many of these statutes.

177. ERIC Hobsbawm, THE AgE OF EMPIRE: 1875-1914 3 (1989) ("For all of us there is a twilight zone between history and memory; between the past as a generalized record ... and the past as a remembered part of, or background to, one's own life.”). 